\title{
MEA CULPA, SUA CULPA, TUA MAXIMA CULPA: COLLECTIVE RESPONSIBILITY AND LEGAL JUDGMENT MEA CULPA, SUA CULPA, TUA MAXIMA CULPA:
RESPONSABILIDADE COLETIVA E JULGAMENTO LEGAL
}

\author{
Nergis Canefe* \\ Associate Professor, Departments of Political Science and Public Policy, \\ Administration and Law (Joint Appointment), York University, Toronto, Canada
}

Submissão em 27/04/2017

Aprovação em 05/06/2017

DOI: http://dx.doi.org/10.21671/rdufms.v3i1.3542

\begin{abstract}
Ascertaining litigation for crimes reaching the dimensions of crimes against humanity remains an elusive quest. This is despite the precedents set by post-WWII trials in international criminal law and post-conflict justice. Ranging from the contribution of Nuremberg to the substantive development of international criminal law, to the philosophical evaluation of legalism in post-conflict systems of justice, the persistent significance of the Nuremberg legacy is indeed worthy of attention. In this article, the Nuremberg legacy is reexamined from the perspective of collective responsibility for mass crimes. The Nuremberg Judgment is counted as the benchmark in international law for the definition and adjudication of individual accountability for war crimes and crimes against humanity and redefined the nature of legal responsibility. However, concurring with Karl Jaspers, I argue that for such crimes, the judgment cannot emanate from the courtroom alone. In this vein, the paper revisits theories of collective responsibility and culpability. Due to the extensive nature of harm involved in historic injustices, I posit that individual responsibility argument waged against historic justice claims carries forward a great deficit. Historic injustices and the harms they generate are best understood as collective harms. The response to such harms must have a collective component as well, and the remedies offered are only meaningful in a social and political context. One common form of such harm, constitutive harm, significantly differs from the aggregative accounts of harm generally used by standard
\end{abstract}

${ }^{*}$ The author wishes to thank Professor Carl Ehrlich for introducing her to Karl Jaspers' thought and sharing his late father Professor Leonard Ehrlich's pathfinder work on Jaspers, who was a student of the philosopher himself, with great generosity. 
individual criminal litigation processes. It is the type of harm that people suffer as members of historically wronged groups and communities and often in the hands of the state that was poised to protect them. Therefore, historic injustice cases require a different account of responsibility, one that cannot be harnessed solely based on individual responsibility argumentation within the context of domestic or international criminal justice jurisprudence. The article urges that we make room for considerations pertaining to collective responsibility as a moral obligation, thus providing a context within which legal judgment for egregious crimes could be firmly situated and historicized.

Keywords: Collective responsability; International criminal Law; Historical injustices; Collective harms; Moral obligation.

Resumo: Estabelecendo litigância por crimes que atingem as dimensões de crimes contra a humanidade continua sendo uma missão evasiva. Isto ocorre apesar dos precedentes estabelecidos pelos julgamentos pós-Segunda Guerra Mundial no direito penal internacional e na justiça pós-conflito. Variando da contribuição de Nuremberg para o desenvolvimento substantivo do direito penal internacional, para a avaliação filosófica do legalismo em sistemas de justiça pós-conflito, o significado persistente do legado de Nuremberga é realmente digno de atenção. Neste artigo, o legado de Nuremberga é reexaminado a partir da perspectiva da responsabilidade coletiva por crimes de massa. o julgamento de Nuremberga é considerado referência no direito internacional para a definição e adjudicação da responsabilidade individual por crimes de guerra e crimes contra a humanidade e redefiniu a natureza da responsabilidade legal. No entanto, concordando com Karl Jaspers, argumento que, para tais crimes, o julgamento não pode emanar apenas do tribunal. Nesse sentido, o artigo revisa teorias de responsabilidade coletiva e culpabilidade. Devido à extensa natureza dos danos envolvidos em injustiças históricas, considero que o argumento da responsabilidade individual contra reivindicações históricas de justiça traz um grande déficit. As injustiças históricas e os danos que geram são melhor entendidos como danos coletivos. A resposta a tais danos também deve ter um componente coletivo, e os remédios oferecidos só são significativos em um contexto social e político. Uma forma comum de tais danos, o dano constitutivo, difere significativamente dos relatos agregadas de danos geralmente utilizados pelos processos individuais padrões de litigância criminal. É o tipo de dano que as pessoas sofrem como membros de grupos e comunidades historicamente injustiçados e muitas vezes nas mãos do Estado que foi preparado para protegê-los. Portanto, os casos de injustiça histórica requerem uma responsabilidade diferenciada, que não pode ser aproveitada exclusivamente com base na argumentação de responsabilidade individual no contexto da jurisprudência de justiça penal nacional ou internacional. $O$ artigo insiste em que demos lugar a considerações relativas à responsabilidade coletiva como uma obrigação moral, fornecendo, assim, um contexto dentro do qual o julgamento legal para crimes atrozes possam ser firmemente situados e historicizados.

Palavras-chave: Responsabilidade coletiva; Direito criminal internacional; Injustiças históricas; Danos coletivos; Obrigação moral.

SUMÁRIO: 1. Introduction. 2. Beyond Eichmann: on the necessity of judgment. 3. Towards an engaged theory of judgment and collective responsibility. 4 . Collective responsibility and legal judgment in international law: the jaspers alternative? 5. Moral responsibility as an epicurian cure for the conundrums of international criminal law? 6. Collective responsibility and the distribution of blameworthiness. 7. Conclusion: the dilemma of the sum total versus its constitutive parts. 
ad auctores reddit sceleris coacti culpa -the guilt of imposed crimes lies on those who impose them.

Seneca. ${ }^{1}$

cavendum est ne major poena, quam culpa, sit--care should be taken in all cases, that the punishment not exceed the guilt.

Cicero. $^{2}$

\section{INTRODUCTION}

If only we would abide by the ethical guidelines offered by the Romans, problematic aspects of collective responsibility in law and legal morality could perhaps be successfully avoided. However, a harmonious relationship between social life and political peace is not so easy to attain or sustain during deep crises and mass violence in our current era. Issues pertaining to justice and personal desert at times of turmoil and uproar such as genocidal violence, ethnic cleansing or crimes against humanity cannot be reduced to that of proven links between punishable individual actions and responsibility-cum-accountability. Intricacies of mass political violence and societal crimes render such direct and methodical solution inapplicable or lacking.

How far are our lives implicated by what other people do to each other indirectly? How much responsibility falls on our shoulders by the harms that flow from social, economic, and political institutions that we are embedded in even if we do not inflict harm while occupying positions of authority? Do our relations as individuals to spheres of collective existence lead to complicity and collective responsibility in the event that they lead to harm for select sectors of the society $?^{3}$ Indeed, the relationship between collective responsibility and individual guilt or accountability is a very critical albeit difficult one, often avoided

\footnotetext{
${ }^{1}$ See the Latin-English dictionary Eudict online at http://www.eudict.com/?lang=lateng\&wor$\mathrm{d}=\mathrm{ad} \% 20$ auctores\%20redit\%20sceleris\%20coacti\%20culpa [21.03.2017] For the full text of Seneca's work on Melancholy from which this quote comes, see http://www.gutenberg.org/files/10800/10800-h/ampart1.html [21.03.2017].

${ }^{2}$ For the translations, see Eudict at http://www.eudict.com/?lang=lateng\&word=cavendum\%20 est $\% 20$ ne $\% 20$ major\%20pœna,\%20quam\%20culpa,\%20sit;\%20et\%20ne\%20iisdem $\% 20$ de $\% 20$ causis\%20alii\%20plectantur,\%20alii\%20ne\%20appellentur\%20quidem [21.03.2017].

${ }^{3}$ As Christopher Kutz' work shows, the two prevailing theories of moral philosophy, Kantianism and consequentialism, both have difficulties resolving problems concerning complicity in collective violence. See Christopher Kutz, Complicity: Ethics and Law for a Collective Age (Cambridge University Press, 2007). Also see the classical work of Andrew Arato, "The Bush Tribunals and the Specter of Dictatorship" (2002) 9 Constellations 457.
} 
entirely in international criminal law. It provides a precious point of entry to the nature of our relations with the society and the state, which we are a part of and for which we are the harbingers of legitimacy. In this article, I posit that legal scholarship needs a richer theory of accountability in which our understanding of individual responsibility in relation to societal acts of violence not only allows for but demands an analysis of collective action. Here, I will argue that what should be sought after is not more complicated punishment schemes but rather a substantive way of addressing harm we give to each other both by commission and by omission. ${ }^{4}$ In this context, intentional and purposeful collective action, collective moral responsibility and collective guilt, individual responsibility for (and in) collective wrongs, collective legal obligations to victims of societal and political crimes, and individual moral responsibility with regard to wrongful social and political acts constitute key entries for having a meaningful politicolegal debate on collective responsibility and legal judgment.

In the following pages, I will pursue these questions in a context originally set by Hannah Arendt's work on legal judgment. In Eichmann in Jerusalem, her account of the trial of Adolf Eichmann, Arendt used the phrase "the banality of evil," describing how a man who was neither a monster nor a demon could nevertheless be an agent of the most extreme and evil acts of violence and destruction. ${ }^{5}$ This subsequently prompted her to readdress fundamental questions and concerns about the nature of [collective] violence and our making of moral choices. Indeed to be seen as a sequel to her work on Eichmann in that regard, her Responsibility and Judgment gathers together unpublished writings from the last decade of Arendt's life. ${ }^{6}$ In these later works, she strived to explicate the meaning of the Eichmann trial in Jerusalem much further. At the heart of this series of essays lies a profound ethical investigation concerning traditional moral

\footnotetext{
${ }^{4}$ On this issue, see Larry May, Crimes Against Humanity: A Normative Account. (Cambridge University Press, 2007). May's work is the first book-length treatment of the philosophical foundations of international criminal law. His focus is on the moral, legal, and political questions that arise when individuals who commit collective crimes, such as crimes against humanity, are held accountable by international criminal tribunals. These tribunals challenge one of the most sacred prerogatives of states - sovereignty -. Breaches to this sovereignty can be justified only in limited circumstances, which constitutes minimalist threshold of the justification for international prosecution. May's work begins an important discussion inside the field of international criminal law. What I purport here is to carry this discussion forward in conjunction with moral theories of judgment in applied legal philosophy and legal ethics.

${ }^{5}$ See Hannah Arendt, Eichmann in Jerusalem (Penguin, 1963). Also see Jacob Robinson, And the Crooked Shall Be Made Straight the Eichmann Trial, the Jewish Catastrophe, and Hannah Arendt's Narrative (MacMillan, 1965), and, Seyla Benhabib, "Arendt's Eichmann in Jerusalem" in Dana Richard Villa, ed. The Cambridge Companion to Hannah Arendt (Cambridge University Press, 2000) at 65-85.
}

${ }^{6}$ See Hannah Arendt, Responsibility and Judgment (Schocken Books, 2003). 
truths being used as politico-legal standards to judge criminality pertaining to mass violence.

Arendt's analysis on judgment tests our ability to distinguish good from evil and right from wrong to its limits. The radical evil she had addressed in her earlier work on totalitarianism evolves into her work on a much more pernicious evil, almost independent of political ideology, whose execution is limitless when the perpetrator feels no remorse and can erase the memory of his/her acts as soon as they are committed. For such acts, individual criminal responsibility, even if it comes tied to mass crimes such as crimes against humanity, does not suffice for us to understand the true nature of the harm and wrong implicated by such criminal acts. Arendt's conclusion has serious repercussions for contemporary conceptions of accountability at the level of international criminal law and this article is a token of dedication to think further in that vein.

Individual autonomy is an ideal that refers to the capacity to be one's own person, to live one's life according to reasons and motives that are taken as one's own and not the product of manipulative, coercive or distorting external forces. It is the central value in the Kantian tradition of moral philosophy but it is also given fundamental status in John Stuart Mill's and his successors version of utilitarian liberalism. Examination of the concept of autonomy also figures centrally in debates over legal freedoms and rights (such as freedom of speech and the right to privacy), as well as moral and political theory pertaining to justice. ${ }^{7}$ In the realm of moral theory, seeing autonomy as a foundational value stands in contrast with alternative frameworks such as ethics of care and ethics of virtue. However, those are rarely brought into debates on criminal justice. Autonomy has traditionally been thought to connote independence and hence prioritizes individual agency in both moral thinking and political decisions. In the context of individual autonomy and the banality of evil, however, the existing arsenal of concepts we have do not suffice to deal with the massive problem in hand, namely, how to understand the weight of individual choices in producing such unforgivable forms of societal and mass harm.

In the following pages, I argue that we have to turn to another concept, one that Arendt was not contend with at all, in order to make sense of this conundrum

\footnotetext{
${ }^{7}$ See Immanuel Kant, Grounding for the Metaphysics of Morals, in I. Kant, Ethical Philosophy, James W. Ellington, trans. (Indianapolis, IA: Hackett Publishing [1785/1983]) and his Metaphysical Elements of Justice, John Ladd, ed. (Indianapolis, IN: Hackett, [1797/1999]); John Stuart Mill, On Liberty, David Spitz, ed. (Norton, [1859/1975]). Also see Joseph Raz, Joseph, The Morality of Freedom (Clarendon 1986); Jennifer Nedelsky, "Reconcieving Autonomy: Sources, Thoughts, and Possibilities" (1989) 1 Yale Journal of Law and Feminism 7, and, Ben Coburn, Autonomy and Liberalism (Routledge, 2010).
} 
of common-place and rule-bound choices made by individuals leading to collective forms of violence and societal wrongdoing. This is the concept of collective responsibility. ${ }^{8}$ In legal philosophy, starting with Joel Feinberg's work, this debate has been kept alive like a slowly burning flame always looming at the background of questions pertaining to accountability. ${ }^{9}$ It also received ire from many corners as it goes against the basic principle that no one can be responsible, in the properly ethical or criminal sense, for the conduct of another and that responsibility squarely belongs to the individual. However, the implications of this principle are far-reaching and much more damaging than is evident at first, and reflecting upon them led at least a small group of scholars and legal thinkers to withdraw the assent which they might otherwise accord to this limited and strict view of responsibility. In international criminal law, reverting to the barbarous notion of collective or group responsibility for litigation purposes is considered an absolute derogation of rights, and rightfully. What I am pursuing here is something rather different: it is the notion of accountability for atrocities as societal responsibility in a distinctively moral and socio-political sense. ${ }^{10}$

My purpose is not to attribute a diminishing importance to causation in law and moral philosophy. In ideal circumstances where harm is not involved, the outcome of an act does not and should not effect our assessment of the moral quality of the act. In cases of acts blameworthy due to their resulting in harm or near harm, however, should our moral assessment be neutral? Furthermore, should we not look elsewhere other than the individual mens rea component for criminal acts that require societal endorsement, support and condoning? Should larger outcomes never matter in our moral assessment of a person's individual acts? Back in 1968, when D. E. Cooper proposed the thesis that collectives can be held responsible in a sense not reducible to the individual responsibility of members of the collective. He also stated clearly that it is not moral responsibility

\footnotetext{
${ }^{8}$ In legal scholarship, the concept was taken up mainly in the context of blameworthiness for litigation purposes. The first important intervention in this regard came in the form of the suggestion that actions could serve as legitimate bases for blame without objective wrongdoing per se. Here, intent is identified as the key. See Jan Narveson, "Collective responsibility" (2002) 6 The Journal of Ethics 179.

${ }^{9}$ See Joel Feinberg, "Collective responsibility" (1968) 65 The Journal of Philosophy 674. Also see Virginia Held, «Can a random collection of individuals be morally responsible?» (1970) 67 The Journal of Philosophy 471. Held's article was taken up and reevaluated extensively in Stanley Bates, «The Responsibility of» Random Collections» (1971) 81 Ethics 343.

${ }^{10}$ Starting with Hywel D. Lewis, "Collective responsibility" (1948) 23 Philosophy 3, the spectrum of works to be consulted in this regard include Larry May, Sharing responsibility. (University of Chicago Press, 1992); Larry May \& Stacey Hoffman, eds. Collective responsibility: Five decades of debate in theoretical and applied ethics (Rowman \& Littlefield Publishers, 1992); Angelo Corlett, Collective responsibility (John Wiley \& Sons, Ltd, 2001), and, Christopher Kutz, Complicity: Ethics and law for a collective age (Cambridge University Press, 2007).
} 
which is involved in such an askance of accountability. ${ }^{11}$ I strongly concur with Cooper and invite us to revisit the collective responsibility debate at the current historical junction of criminal acts, especially those pertaining to civil war, military occupation and neo-colonialism, almost all of which prove beyond reach of current regime of accountability in international criminal law barring universal jurisdiction jurisprudence. We have nothing to loose in the regard, and perhaps a lot to gain, by at least temporarily suspending our overdependence on legal institutions for finding cures to our societal ills via litigation based on individual accountability.

\section{BEYOND EICHMANN: ON THE NECESSITY OF JUDGMENT}

Half a century ago, while writing Eichmann in Jerusalem, Hannah Arendt struggled to defend the possibility of judgment against the manifold problems we encounter in our attempts to offer legally valid and morally meaningful verdicts concerning those who had committed crimes in morally bankrupt and legally defunct communities. ${ }^{12}$ No doubt some of Arendt's conclusions concerning Eichmann are equivocal. Her theory of judgment in the Eichmann manuscript itself could even suggest that Arendt may have been suffering from remaining trapped within a set of Kantian assumptions in her philosophy of history, and thus ended up defining the question of freedom to act in a binary way. In contradistinction, proposing that judgment has an antinomical character and emphasizing the importance of elements of reason and sense as well as

\footnotetext{
${ }^{11}$ See the Cooper/Downie debate at David E. Cooper, "Collective responsibility" (1968) 43 Philosophy 258 and Robert Silcock Downie, «Collective responsibility» (1969) 44 Philosophy 66. Also see Howard McGary, «Morality and collective liability» (1986) 20 The Journal of Value Inquiry 157.

${ }^{12}$ See Hannah Arendt, Eichmann in Jerusalem, supra note 5 and Hannah Arendt, "Eichmann in Jerusalem: An exchange of letters between Gershom Scholem and Hannah Arendt" (1964) 22 Encounter 51. Commentaries on Arendt's Eichmann in Jerusalem are generally one of two kinds. The first group confronts the historical relevance of Arendt's observations and attempts to ascertain whether her presentation of Eichmann's trial compliments or corresponds to the reality of the incommensurable suffering of the Jewish people during the Second World War. The second variety focuses on the meaning of her term 'the banality of evil' by placing Arendt in a long tradition of moral and political philosophy concerned with the problem of judging evil and harm. See, for instance, Peg Birmingham, "Holes of Oblivion: The Banality of Radical Evil," (2003) 18 Hypatia 80. If one is to read Arendt's treatise on Eichmann in light of Walter Benjamin's conceptions of history and storytelling, a third route emerges and it becomes clear that Eichmann in Jerusalem was not intended to reflect reality objectively. On the contrary, Arendt aimed at avoiding the cold and detached neutrality of historicism, as she calls it the 'tradition of sine ira et studio', the Latin term meaning "without anger and fondness" or "without hate and zealousness." For Arendt, such an approach to Eichmann and the crimes he committed would represent a renunciation of his and others' responsibility for them. See Annabel Herzog, "Reporting and Storytelling: Eichmann in Jerusalem as Political Testimony” (2002) 68 Thesis Eleven 83.
} 
circumstance may allow for a better understanding of the collective nature of responsibility for societal crimes and freedom to be redefined in this particular context. ${ }^{13}$ In Theodore Adorno's terms, judgment becomes the very test for the limits of agency and autonomy suffered by the potentially free but essentially 'unfree subjects' of modernity. ${ }^{14}$

Contemporary readers of Eichmann in Jerusalem sometimes cast it as a juridical text, due to the fact that presumably it is concerned more with justice than politics or ethics. Such juridical readings of Arendt's treatise on Eichmann in particular and crimes against humanity in general, focus attention on what Arendt calls the primary challenge of the case-namely, the trial of Eichmann's unprecedented crimes against humanity in a domestic court. ${ }^{15}$ However, putting so much emphasis on the nature of the crimes against humanity legislation leads to our failing to attend Arendt's principled resistance to a juridical response in such cases. This is clearly evidenced in her criticism of both procedural and substantive aspects of the Jerusalem Court's ruling. Taking heed from Arendt's resistance to the Court's approach, here I argue that Eichmann in Jerusalem does not authorize a juridical approach to the unprecedented and egregious crimes under discussion, namely crimes against humanity. Instead, it leads us to think

\footnotetext{
${ }^{13}$ For a timely discussion on the presence of 'ethical' narratives and images of the Holocaust in debates and demonstrations around the recent conflicts in Gaza and the need for a new form of foundation for legal reflection, legal judgment and legal justice in the Arendtian tradition of rethinking law, see David Seymour, "From Auschwitz to Jerusalem to Gaza: Ethics for the Want of Law" (2011) 6 Journal of Global Ethics 205.

${ }^{14}$ During the 1960s, Theodore Adorno became the most prominent challenger of both Karl Popper's philosophy of science and Martin Heidegger's philosophy of existence. The scope of Adorno's influence stems from the interdisciplinary character of his research and of the Frankfurt School to which he belonged. The thoroughness with which he examined Western philosophical traditions from Kant onward, and the radicalness of his critique of contemporary Western society remain pivotal for any critique of moral claims concerning individual autonomy. It should also be noted that for both Adorno and Arendt, a critical reading of Kant's Third Critique is the indispensable means by which it is possible to locate a path pointing beyond the chiasmic structure suggested by the tradition of natural history. See Theodore Adorno, Can One Live after Auschwitz?: A Philosophical Reader, ed. R. Tiedemann, trans. R. Livingstone et al. (Stanford University Press, 2003). Also see Susan Buck-Morss, The Origin of Negative Dialectics; Theodor W. Adorno, Walter Benjamin and the Frankfurt Institute (Free Press, 1977).

${ }^{15}$ In the course of her 1964 interview with Günter Gaus, Arendt stated her distaste for "intellectual business" that arose from witnessing the widespread and "relatively voluntary" Gleichshaltung (coordination) of German "intellectuals" with the Nazis in 1933. This raises the following question: what does lack of conscientious engagement with one's own acts--as exemplified by Eichmann-tell us about the relation between reason, judgment and harm? For a select list of critical readings on the subject, see Shoshana Felman, "Theatres of Justice: Arendt in Jerusalen, The Eichmann Trial and the Redefinition of Legal Meaning in the Wake of Holocaust" (2001) 27 Critical Inquiry 201; Paul Formosa, "Thinking, Conscience and Acting in the Face of Mass Evil" In Andrew Schaap, Danielle Celermajer and Vrasidas Karalis, eds., Power, Judgement and Political Evil: In Conversation with Arendt (Ashgate, 2010); Roger Berkowitz, Jeffrey Katz \& Thomas Keenan, eds. Thinking in Dark Times: Hannah Arendt on Ethics and Politics (Fordham University Press, 2010).
} 
about the importance of an 'agonistic understanding of law. ${ }^{16}$ Such a take would foreground law's dependence on political acceptance or contestation of legal strictures, maxims and constraints. Especially with the advent of mass crimes such as crimes against humanity, Arendt asks us to attend to law's dependence on the human capacity to resist legal compulsions and urges us to redefine the meaning and merit of legal institutions in light of the responsibility of all concerned for their maintenance, sustenance and functioning. ${ }^{17}$

In her Lectures on Kant's Political Philosophy, Arendt detranscendentalizes Kant by linking Kant's judgment of taste to empirical sociability and lived experience. ${ }^{18}$ However, she does not confuse Kant's idea of enlarged thinking with an actual dialogue with others. Instead, she introduces the notion of interdependence between judgment and speech, or communication. In this sense, Arendt interprets Kant's Critique of Judgment not as a theory of aesthetic judgment, but as an answer to the more general question of 'how do I judge?' She also draws a distinction between common sense and community sense, a notion further explored in the work of Jennifer Nedelsky and others writing in the area of human rights. Working with the notion of community sense, Arendt uncovers a foundation not only for humans as political beings but also for the idea of humanity at large. However, this finding is often overlooked in the literature pertaining to her theory of judgment. ${ }^{19}$ In the following pages, I would

\footnotetext{
${ }^{16}$ See Lida Maxwell, "Towards an Agonistic Understanding of Law: Law and Politics in Hannah Arendt's Eichmann in Jerusalem" (2010) 11 Contemporary Political Theory 88. On the issue of morality and politics of law concerning Nazi crimes, see Diana Taylor, "Hannah Arendt on Judgment: Thinking for Politics" (2002) 10 International Journal of Philosophical Studies 151; Craig Reeves, "Exploding the Limits of Law: Judgment and Freedom in Arendt and Adorno" (2009) 15 Res Publica 137; Seyla Benhabib, ed. Politics in Dark Times: Encounters with Hannah Arendt (Cambridge University Press, 2010).

${ }^{17}$ The literature on this debate is immense. For a select set of critical readings that concentrates precisely on this subject, see Samir (2004) "Writing and Judging: Adorno, Arendt and the Chiasmus of Natural History." Philosophy and Social Criticism 30 (4): 445-475; Parekh, Serena (2008) Hannah Arendt and the Challenge of Modernity: A Phenomenology of Human Rights. Routledge; Gandesha, Goldman, Avery (2010) "An Antinomy of Political Judgment: Kant, Arendt and the Role of Purposiveness in Reflective Judgment." Continental Philosophy Review 43 (3): 331-352; Degryse, Anthony (2011) "Sensus Communis as a Foundation for Men as Political Beings: Arendt's Reading of Kant's Critique of Judgment." Philosophy and Social Criticism 37 (3): 345-358; Villa, Dana (2012) From the Critique of Identity to Plurality of Politics: Reconsidering Adorno and Arendt. In Lars Rensmann and Samir Gandesha, eds., Arendt and Adorno: Political and Philosophical Investigations. Stanford University Press.
}

${ }^{18}$ See Hannah Arendt \& Ronald Beiner. Lectures on Kant's political philosophy (University of Chicago Press, 1989).

${ }^{19}$ On this issue, see Ronald Beiner, "Rereading Hannah Arendt's Kant Lectures” (1997) 23 Philosophy and Social Criticism 21; Paul Formosa, "Thiking, Willing, Judging." (2009) 4 Crossroads 53; Avery Goldman, "An Antimony of Political Judgment: Kant, Arendt and the Role of Purposiveness in Reflective Judgment" (2010) 43 Continental Philosophy Review 331; Roger Berkowitz \& Majid Yar, Majid "From Actor to Spectator: Hannah Arendt's Two Theories of Judgment" (2010) 26 Philosophy 
like to bring back this sense of political groundedness of collective action vis-àvis our notions of collective responsibility and concerns pertaining to criminal judgments in this context.

Of Arendt's completed works, the 'Postscriptum' to Thinking, the first volume of The Life of the Mind, and her Lectures on Kant's Political Philosophy are widely considered to be her definitive remarks on judgment. These texts are privileged for two reasons. First, they were written after Arendt's controversial text, Eichmann in Jerusalem. It was Arendt's recognition of the role that Eichmann's inability to think played in his war crimes which motivated her to analyze more fully not only the 'human activity' of thinking, but those of willing, and judging as well. In addition, in both The Life of the Mind and the Kant Lectures, Arendt treats judgment as a distinct human activity with a unique potential. In these later works, though Arendt does indeed reformulate her notion of judgment, she does not depoliticize it. On the contrary, the effects of what Arendt refers to as 'dark times' are long-term and pervasive and, moreover, the function of making judgments within such an expanded context remains politically germane as it was back in the immediate aftermath of WWII.

Specifically, the basic project of Arendt's Lectures on Kant's Political Philosophy could be identified as an attempt to ground the idea of human dignity within the context of the publicly displayed 'words and deeds' that constitute the realm of human affairs and of course, politics. Her attempt to redefine human dignity also involves a strong philosophical response to Plato's impugning of the dignity from the polis. The Kant Lectures bring this distinct philosophical take on the political nature of genuine human conduct to its completion: the enactment of public deeds presupposes a company of engaged spectators who draw meaning by judging what is enacted in the public sphere. In other words, Arendt appropriates and reconceptualizes Kant's work in such a way that judgment, while a distinct faculty, nonetheless retains an utmost political character.

\section{TOWARDS AN ENGAGED THEORY OF JUDGMENT AND COLLECTIVE RESPONSIBILITY}

The notion of collective responsibility would indeed prove legally and morally unsustainable if it is taken to be an unqualified application of the Kantian model of individual moral responsibility to the society at large. ${ }^{20}$ However, it emerges as

and Social Criticism 1, and, Roger Berkowitz, ed. Thinking in Dark Times: Hannah Arendt on Ethics and Politics (Fordham University Press, 2010).

${ }^{20}$ For a strong philosophical critique of the direct application of the Kantian model with reference to legal obligations, see David Copp, "What Collectives are: Agency, Individualism and Legal 
a more coherent phenomenon should we choose to formulate it in terms of moral choices leading to willing acts that are above and beyond the singular capacity of autonomous individual agents. ${ }^{21}$ Our desire for accountability against actions of groups and institutions that cause harm and injustice in the society at large could be at least partially satiated if we allow the lens of collective responsibility to refocus our attention from intentionality of harm to the processes pertaining to production or possible curtailment of it. ${ }^{22}$

In the field of legal theory, the biggest controversy concerning collective responsibility is about the method of its attribution. Without grounds for ascertaining collective responsibility, received wisdom has it that there is no possibility for judgment. Legally speaking, collective responsibility is defined mainly in terms of duties to respond to the victims of collective crimes. Therefore, it invokes a reverse reading that is heavily situation-bound. Accordingly, reasonable fear on the part of the victimized groups and communities creates duties to respond that concern members of the perpetrating group or the society

Theory" (1984) 23 Dialogue 249 and Kendy M. Hess, "Because They Can: The Basis for the Moral Obligations of Collectives" (2014) 38 Midwest Studies in Philosophy 203. Philosophers who reject rank individualism and a self-interested legal culture tend to reject schisms between legal norms and community values, institutionalized separation of law from morals, supremacy of intricate regimes of legislation and adjudication over social truths. They also tend to stand against the culture of rampant litigation for seeking justice. The alienation of individuals from each other and from their communities is so easily bred within highly complex political and legal systems. This issue is squarely taken up by communitarian critiques of law in legal theory. See for instance, Chantal Mouffe, "Democratic citizenship and the political community" in her Dimensions of radical democracy: Pluralism, citizenship, community (Verso, 1992) at 225-239.

${ }^{21}$ On the legal significance of the concept, see Joel Feinberg's work, especially his Doing and deserving; essays in the theory of responsibility, supra note 6. Also see Linda Raznik, "Collective Responsibility and Duties to Respond" (2001) 27 Social Theory and Practice 455; Iris Mario Young, "Responsibility and Global Justice: A Social Connection Model" (2006) 23 Social Philosophy and Policy 102; Ronald Tinnevelt, "Collective Responsibility, National Peoples and the International Order" (2009) 2 Netherlands Journal of Legal Philosophy 147, and, Margaret Gilbert, "Shared Intention and Personal Intentions" (2009) 144 Philosophical Studies 167.

${ }^{22} \mathrm{On}$ the issue of 'communities of judgment', Jennifer Nedelsky makes a strong argument in support of the social foundations of judgment. Nedelsky posits that the debates over 'universal' human rights versus abuses in the name of culture and tradition are best understood as conflicts between different communities of judgment. Using Hannah Arendt's work on judgment as a starting point, she addresses the problems and possibilities that arise out of Arendt's view that judgment relies on a 'common sense' shared by members of a community of judging subjects. Nedelsky points out that 'common sense,' 'community' and 'other judging subjects,' are concepts not fully developed in Arendt's theory. This leads to her account of the concept of 'enlarged mentality' as the basis for human rights. There remains, however, the thorny question of how one could decide to change or oppose 'common sense' when it seems to be presupposed for judgment to be possible. As we attend to concrete manifestation of the problem of judgment across communities, our linked capacities for autonomy and judgment emerge as complementary rather than contradictory faculties and capacities. Nedelsky's insights on Arendt's theory of judgment prove most useful in the context of collective responsibility. See Jennifer Nedelsky, "Communities of Judgment and Human Rights" (2000) 1 Theoretical Inquiries in Law 245. 
at large. This phenomenological account of collective responsibility may offer us a justification for making judgments about collective responsibility that are compatible with the separateness and autonomy of persons. However, it still leaves a number of critical questions unattended. For instance, could we defend the claim that collective responsibility can be assigned based on group membership? I would argue that this is indeed a dangerously erroneous approach to the subject. For the purpose of examining the nature of legal judgment under the strenuous circumstances of egregious crimes, collective responsibility is best understood in terms of societal duties to respond to the victims of collective crimes rather than attribution of collective guilt and culpability. ${ }^{23}$

Responsibilities moral agents have in relation to global structural social processes with unjust consequences constitute a good case in point. How ought moral agents, whether individual or institutional, conceptualize their responsibilities in relation to global injustice, for instance, if they do so at all? In this case, a model of collective responsibility deriving from global social connections and interdependencies may serve the purpose of forming the foundation for defining obligations of justice arising from structural social processes. As detailed in the work of Iris Marion Young, such a social connection model of responsibility dictates that all agents who contribute by their actions to the structural processes that produce injustice have responsibilities to work to remedy these injustices. ${ }^{24}$ This is quite different from the standard model of responsibility putting emphasis on liability. This alternative model does not isolate perpetrators. It also judges background conditions of action as well as consequences. It is forward looking and it relies upon the responsibility to

\footnotetext{
${ }^{23}$ Plausibly, only moral agents can bear action-demanding duties and thus only moral agents could be subjected to criminal attribution. This standard places serious constraints on the determination of which collectives can bear action-demanding duties or be rendered accountable for societal harm. It is equally erroneous to assume that individual agents can bear duties and full scale of legal obligations regarding actions that only a collective could perform. This leaves us at a loss when assigning duties in circumstances where only a collective could perform some morally desirable action and no collective exists. It also causes problems concerning attribution of guilt and adjudication of crimes involving collectivities. Collectivization of duties and introduction of notions such as 'public responsibility' may alleviate some of the problem. Specifically, we could define individual duties to take steps towards forming a collective sense of responsibility, which then incur a duty over collective and cumulative action. However, this problem cannot be so easily overcome at the adjudication of mass crimes and attribution of guilt. See Marion Smiley, "From Moral Agency to Collective Wrongs: Rethinking Collective Moral Responsibility" (2010) 1 Journal of Law and Policy 171; Tracy Isaacs, Moral Responsibility in Collective Context (Oxford University Press, 2011), and, Anne Schwenkenbecher, "Joint Duties and Global Moral Obligations" (2013) 26 Ratio 310.

${ }^{24}$ See Iris Marion Young, Responsibility for Justice (Oxford University Press, 2011). On the application of restitutive justice at a global scale, see Jacob Schiff, "Confronting Political Responsibility: The Problem of Acknowledgement" (2008) 23 Hypatia 99; Henning Hahn, "The Global Consequences of Participatory Responsibility" (2008) 5 Journal of Global Ethics 43, and, Todd Calder, "Shared Responsibilty, Global Structural Injustice and Restitution" (2009) 36 Social Theory and Practice 263.
} 
be shared. Furthermore, it can be discharged only through collective action. I would argue that Marion Young's social connection model and Arendt's notion of community sense have more in common than at first meets the eye, and this is a hopeful overlap for any future discussion on collective responsibility in international criminal law.

If so, in terms of committal of crimes, how could we define the legal threshold for determining whether a collective shares the intention to harm a select group, which is the distinctive feature of collective as opposed to individual responsibility? There are at least three criteria of adequacy for an account of shared criminal intention, namely the disjunction, concurrence, and, obligation criterium. ${ }^{25}$ Accordingly, people share an intention when and only when they are jointly committed to intend as a body to commit an act in the future. In other words, there is an element of premeditation as well as active participation towards the committal of violent act or acts. The problem is, in the case of societal and political crimes, many instances of wrongdoing and violence appear to be of a distinctly spontaneous and collective kind without clear signs of premeditation. When, for example, one group commits genocide against another, the genocide is collective in the sense that the wrongfulness of genocide is morally distinct from the aggregation of individual murders that make up the genocidal killings in their entirety. And yet, it may not be possible to either prove or indeed to find a clear framework for shared intentions for genocide for each of the perpetrators of criminal acts. The problem, which I would rephrase as the problem of collective wrongdoing, is how to assign blame for distinctly collective acts of violence to individual contributors when none of those individual contributors is singularly guilty of the Wrongdoing with a capital $\mathrm{W}$ in question.

In such instances, suffice it to say that intention is not merely a private mental act known only by the people who express their intentions in public. Rather, intention is a communal act, for the fact that observable circumstances and consequences determine the justiciability of intention in criminal law. Here, Christopher Kutz's Complicity Principle provides a good starting point for tackling the problem of intentionality in societal and political mass crimes. ${ }^{26}$ Kutz's work

\footnotetext{
${ }^{25}$ See Thomas Scanlon, What We Owe to Each Other. (Belknap Press of Harvard University Press, 1998); Michael Bratman, Faces of Intention: Selected Essays on Intention and Agency (Cambridge University Press, 1999); Elisabeth Pacherie, "Framing Joint Action" (2011) 2 Review of Philosophy and Psychology 173, and, Darrell Cole, "War and Intention" (2011) 10 Journal of Military Ethics 174. ${ }^{26}$ See Christoper Kutz, Complicity: Ethics and Law for a Collective Age (Cambridge University Press, 2000). On the issue of collective complicity, also see Larry May, "Complicity: Ethics and Law for a Collective Age" (2002) 111 Philosophical Review 483; Garrath Williams, "No Participation without Implication: Understanding the Wrongs we do Together" (2002) 8 Res Publica 201; Torbjorn Tannsjo, "The Myth of Innocence: On Collective Responsibility and Collective Punishment" (2007)
} 
examines the relationship between collective responsibility and individual guilt. He presents a rigorous philosophical account of the nature of our relations to social groups in which we participate and then links this debate to contemporary moral theory. For him, there are two prevailing theories of moral philosophy, Kantianism and consequentialism, both of which have difficulties dealing with the issue of complicity. For Kutz, similar to Arendt, a richer and more grounded theory of accountability demands that our understanding of collective action not only allows but calls for redefining individual responsibility in collective settings via complicity.

No doubt Kutz' principle ought to be expanded in order to link it with the legal phenomenon of attribution of collective responsibility. In this context, the view I purport is that individuals are blameworthy for collective harms insofar as they knowingly participate in those harms, and that said individuals remain blameworthy regardless of whether they succeed in making a causal contribution to those harms. ${ }^{27}$ In this sense, my argument for collective responsibility is

36 Philosophical Papers 295; Tracy Isaacs, Moral Responsibility in Collective Contexts (Oxford University Press, 2011); Uwe Steinhoff, "Rights, Liability and the Moral Equality of Combatants" (2012) 16 Journal of Ethics 339, and, Brian Lawson, "Individual Complicity in Collective Wrongdoing" (2013) 16 Ethical Theory and Moral Practice 227. Over the past decade or so political leaders around the world have begun to apologize for, and seek reconciliation between perpetrators and victims of large-scale moral wrongs such as slavery, past campaigns of ethnic cleansing, and official regimes of racial segregation. This movement towards a politics of 'moral healing' and the emergence of an official regime of requesting forgiveness is in effects at odds with full-fledged reconciliation concerning societal wrongs, unless it leads to concrete policies of amelioration, structural change and implementation of restorative justice measures. For wrongs caused by state-sanctioned moral atrocities, and, requiring mass participation and endorsement, interpersonal reconciliation is not likely to be a promising model for providing closure. In this context, Isaacs' work is particularly relevant. She relates intentional collective action to collective moral responsibility, as distinct from collective guilt. She also traces the pedigree of individual responsibility for (and in) collective wrongs and links collective obligations with individual obligations. The remaining question, at least for the criminal law context, pertains to individual moral responsibility and possibilities of accountability in wrongful and harmful social and political practices. An interesting case in this regard is the matter of combatants discussed by Steinhoff. According to the dominant position in the just war tradition from Augustine to Anscombe and beyond, there is no "moral equality of combatants" for criminal justice purposes. In other words, combatants participating in a justified war may kill their enemy combatants participating in an unjustified war. In the meantime, where combatants violate the rights of innocent people-known as collateral damage in humanitarian law, they are in fact liable to attack by the combatants even on the unjustified side for self-defense. That fact on its own gives us a hint about the fluidity of the concepts of liability, culpability and accountability even under the most rigid circumstances such as active warfare.

${ }^{27}$ In support of my proposition, see Margaret Gilbert, Sociality and Responsibility: New Essays in Plural Subject Theory (Rowman \& Littlefield Publishers, 2000). One of the most distinguished social philosophers of our times, Margaret Gilbert develops her arguments around the notion of plural subject theory of human sociality, first introduced in her On Social Facts and Living Together. See Margaret Gilbert, Living together: Rationality, sociality, and obligation (Rowman \& Littlefield Publishers, 1996) and her earlier work, On social facts (Princeton University Press, 1992). In Sociality and Responsibility, Gilbert then presents an extended discussion of her proposal that joint commitments inherently involve obligations and rights, and thus proposes a new theory of obligations and rights that deviates from individualistic agency arguments. Presenting political

Revista DIREITO UFMS | Campo Grande, MS | v.3 | n.1 | p. 53 - 89 | jan./jul. 2017 
based on contra-factual reasoning. For instance, if a collective takes no active responsibility for the conservation of life and livelihood of all of its members but especially ignores those with vulnerabilities, then it is right to presume that there emerges collective responsibility for the harm ensued from lack of provision for any such required protections. ${ }^{28}$ This is one way to avoid the problem of intentionality that clouded Arendt's path in terms of identifying wrongdoing that is not seen or known as wrongdoing by either the person who commits it or by those who condone it.

At this point, the writings of David Miller on national responsibility, read along Karl Jasper's work on societal responsibility, are of great relevance. Starting with Miller, in his work on national responsibility and global justice, he conceptualizes and justifies a particular model of national responsibility--a model that may be helpful in devising a wholesome approach to collective responsibility in justice terms. ${ }^{29}$ His conceptualization proceeds in two steps. He starts by developing two models of collective responsibility, the like-minded group model and the cooperative practice model. He then proceeds to discuss national responsibility as a species of collective responsibility, and argues that nations have features such that both models of collective responsibility apply to them. I would argue that Miller's like-minded model does not provide a plausible conceptualization of collective responsibility in the politico-legal realm at all as it tends to rely upon

obligation, collective remorse, collective guilt, shared intention and important classes of rights and obligations from a plural subject theory perspective, Gilbert's work is very relevant to legal scholars who engage with the subject of collective responsibility. Also see Margaret Gilbert, "Collective guilt and collective guilt feelings" (2002) 6 The Journal of Ethics 115 and her Joint commitment: How we make the social world (Oxford University Press, 2015).

${ }^{28}$ For a strong take on environmental justice and collective responsibility, see Mary Oksanen, "Species Extinction and Collective Responsibility" (2007) in The Proceedings of the Twenty-First World Congress of Philosophy (Vol. 3 at 179-183). On the issue of what we owe to the world at large, David Zoller argues that while it is well recognized that many everyday consumer behaviors, such as purchases of sweatshop goods, come at a very heavy cost to the global poor, it has proven difficult to argue that contributors are somehow morally complicit in those outcomes. The problem concerning marginal contributions to distant harms stems from lack of explicit knowledge of the consequences aforementioned consumers could have born in mind. Critics of this approach reasonably argue that distant and inadvertent acts that cause harm provide insufficient grounds for moral or legal blame. However, the damage that agents bring about through their contributions to distant collective wrongs ultimately depends upon our morally sparse and individualistic take on everyday purchases and decisions. In this instance, contributors who knowingly disregard distant harms, rather than being reckless or negligent about consequences they could have foreseen, directly perpetuate the moral invisibility and the lack of recognition from which the global poor generally suffer. For Zoller, this provides agents with clearer moral reasons to refrain from knowing participation in unstructured collective harms. See David Zoller, "Moral Responsibility for Distant Collective Harms" (2015) 18 Ethical Theory and Moral Practice 995. Also see Bjorn Pettersson, "Coresponsibility and Causal Involvement" (2013) 41 Philosophia 847.

${ }^{29}$ See David Miller, "National responsibility and global justice" (2008) 11 Critical Review of International Social and Political Philosophy 383. 
a bucolic, romanticized notion of a nation as an ethically cohesive unit. ${ }^{30}$ The collective practice model, on the other hand, could provide a strong argument for formulating state-based collective responsibility. The standard example used in this context is, of course, conceptualization of crimes pertaining to societal and political violence when one lived under the Third Reich. ${ }^{31}$

In summary, Miller attempts to attribute to nations the kind of responsibility that generally vests in states as legal actors. Unfortunately, models of statist legal responsibility disregard society's inner dynamics. In addition, they sanction the differences between intrastate and interstate forms of law as irremovable. Miller aims to build up the moral and historical prestige of the nation-state to make it a viable agent embracing a claim of universal morality. Miller's nations thus become political organizations capable of instantiating great moral truths. This results in an account that is compassionately cosmopolitan and yet with very little interest in or engagement with local forms of deliverance of justice that relate to mass violence either within the state perimeters or globally induced. ${ }^{32}$

Overall, however, Miller's work raises a number of interesting questions concerning both weak and strong variants of collective responsibility and state-centric law. ${ }^{33}$ For instance, he defends a theory of connections to address

\begin{abstract}
${ }^{30}$ For a critique of Miller's work, see Roland Pierik, "Collective responsibility and national responsibility" (2008) 11 Critical Review of International Social and Political Philosophy 465, and, K. Lippert-Rasmussen, "Responsible nations: Miller on national responsibility" (2009) 2 Ethics \& Global Politics 21.

${ }^{31}$ To reiterate an otherwise well-known historical vignette, Hitler was appointed as the Chancellor of Germany by the President of the Weimar Republic Paul von Hindenburg on January 1933. The Nazi Party then began to eliminate all political opposition and consolidate its power. By 1934 Hitler became dictator of Germany by merging the powers and offices of the Chancellery and Presidency. This was further entrenched by a national referendum held on 19 August 1934, confirming Hitler as the sole Führer (leader) of Germany. Consequently, all power was centralized in Hitler's office, and his word became above all laws. As to be expected, opposition to Hitler's rule was ruthlessly suppressed and members of the liberal, socialist, and communist opposition were killed, imprisoned, or exiled. The implementation of the regime's racial policies culminated in the mass murder of Jews and other minorities in the Holocaust. For a detailed account of law during the Third Reich, see the historical pieces written and published during the Second World War, K. Loewenstein, "Law in the Third Reich" (1936) 45 The Yale Law Journal 716, V. L. Gott, "The National Socialist theory of international law" (1938) 32 The American Journal of International Law 704; as well as the more recent debates such as D. F. Vagts, "International law in the Third Reich" (1990) 84 The American Journal of International Law 661; Martin Lippman, “They Shoot Lawyers Don't They: Law in the Third Reich and the Global Threat to the Independence of the Judiciary" (1992) 23 Cal. W. Int'l LJ 257, and, David Dyzenhaus, "Legal theory in the collapse of Weimar: contemporary lessons?" (1997) 91 American Political Science Review 121.
\end{abstract}

${ }^{32}$ See T. J. Levy, "National and statist responsibility" (2008) 11 Critical Review of International Social and Political Philosophy 485 and Margaret Moore, "Global justice, climate change and Miller's theory of responsibility" (2008) 11 Critical Review of International Social and Political Philosophy 501.

${ }^{33}$ See in particular David Miller, "Collective responsibility and international inequality in the law of peoples" In Rawls's Law of Peoples: A Realistic Utopia? (2006) at 191-205. 
remedial responsibilities amongst states. His interventions on the subject of cosmopolitanism in particular endorse a position where states that are causally and morally responsible for deprivation and suffering in other states may be held remedially responsible for their actions. This is despite the fact that there is no international mechanism to ensure that remedially responsible states would offer assistance to or accountability for the suffering of effected states and societies, other than instances of victor's justice and imposed war reparations. As such, that job squarely falls into the hands of international public law for purposes of enforcement. In this regard, Miller's claims of universal morality as applied to international or transnational law are severely idealistic. In contradiction, I would argue that we must initiate a kind of deflation of both the nation and the state as foundational moral agents. Just as the diminution of responsibility for mass crimes from the collective entirely to the individual is faulty, the aggrandizement of individual moral agency and accountability to the grandiose entity of the state or the construct of the nation as the ultimate truth bearer is equally hyperbolical.

At this point, as an alternative to cosmopolitan and liberal accounts such as Miller's work, I will examine collective responsibility from an outcomes perspective. A central feature of my analysis is to give precision to the idea that moral responsibility implies a reasonable demand and possibility that an agent should have acted otherwise. Allocation of moral responsibility to individuals concerning complex collective actions that result in mass harm is an issue that goes well beyond 'the problem of many hands' as exemplified by the classic

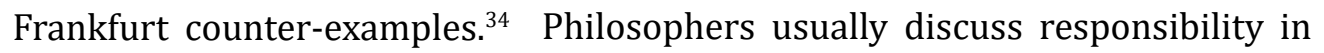
terms of responsibility for past actions or as a question about the nature of moral agency. Yet the word responsibility also ushers in deep concerns about human agency, more so than the answers it possibly elicits in legal terms. This latter take on responsibility also relates it to civic virtues that can be demonstrated both

\footnotetext{
${ }^{34}$ Matthew Braham \& Martin Van Hees "An anatomy of moral responsibility" (2012) 121 Mind 601. As discussed in detail by Braham and Van Hees, Frankfurt cases (also known as Frankfurt counterexamples) were presented by philosopher Harry Frankfurt in 1969 as counterexamples to the "principle of alternate possibilities", which holds that an agent is morally responsible for an action only if that person could have done otherwise. Frankfurt infers that a person could still be morally responsible for what he has done even if he could not have done otherwise. Frankfurt's examples involve agents who are intuitively responsible for their behavior even though they lack the freedom to act otherwise. Frankfurt thus suggests that we question the fallacy of the notion that coercion precludes an agent from moral responsibility. See Harry G. Frankfurt, "Alternate possibilities and moral responsibility" (1969) 23 The Journal of Philosophy 829. This line of reasoning and debate on responsibility under coercion resurfaced in more recent work such as Jay R. Wallace, Responsibility and the Moral Sentiments (Harvard University Press, 1984); John Martin Fischer \& Mark Ravizza, Responsibility and Control: A Theory of Moral Responsibility (Cambridge University Press, 2000), and, Derk Pereboom, Living without Free Will (Cambridge University Press, 2006).
} 
by individuals and organizations/institutions. Such a virtue-based account of responsibility occupies a distinctive place in the context of discussions on moral needs, and moral achievements, of societies, especially for the ones that survived mass political violence and trauma.

This is an opportune moment to bring in Karl Jaspers' work. When Hitler came into power in 1933, Jaspers was taken by some degree of surprise, as he had thought that this movement would destroy itself from within, thus leading to a reorganization and liberation of other political forces active at the time. ${ }^{35}$ His expectations did not materialize and because his wife was Jewish, Jaspers qualified as an enemy of the German state. Consequently, from 1933 onwards, he was excluded from the higher councils of the university. In 1935 the first part of his work on logic, entitled Vernunft und Existenz (Reason and Existenz, 1955), appeared. This was followed by a book on Nietzsche in 1936, an essay on Descartes in 1937; and his Existenzphilosophie in $1938 .{ }^{36}$ Meanwhile, a series of decrees were promulgated against him, including removal from his professorship and a total ban on any further publication. These measures effectively barred him from living and working in Germany. Permission was finally granted to him in 1942 to go to Switzerland, but a condition was imposed by the Nazis that required his wife to remain behind in Germany. He decided to stay with his wife in Germany. In effect, both of them had decided, in case of an arrest, to commit suicide. In 1945 he was told that his deportation was scheduled to take place on April 14. On March 30, Heidelberg was occupied by the American forces and Jaspers and his wife avoided deportation.

Marked by the events of pre-war years, Jasper's detailed philosophical examination of the contemporary state and nature of humankind titled Man in the Modern Age is a seminal work that touches upon precisely the issue of our responsibility for our own and others' future. ${ }^{37}$ Elucidating his theories on a variety of topics pertaining to contemporary and future human existence, the volume meditates upon the tension between mass-order and individual human life, our present conception of human life and the potential for a better future. Jaspers wrote his work before the advent of the Second World War but at a time

\footnotetext{
${ }^{35}$ See the Karl Jaspers entry of Encyclopedia Britanica by Hans Saner at https://www.britannica. com/biography/Karl-Jaspers [21.03.2017].

${ }^{36}$ See Karl Jaspers, Vernunft und Existenz, Groningen: Wolters. Translated as, Reason and Existenz, trans. W. Earle( New York: Noonday Press, 1955); Nietzsche: Einführung in das Verständnis seines Philosophierens, Berlin: de Gruyter. Translated as, Nietzsche: An Introduction to his Philosophical Activity, trans. C. F. Wallraff and F. J. Schmitz (University of Arizona Press, 1965) and Existenzphilosophie, Berlin: de Gruyter. Translated as, Philosophy of Existence, trans. R. F. Grabau (University of Pennsylvania Press, 1971).

${ }^{37}$ See Karl Jaspers, Die Geistige Situation der Zeit, Berlin: de Gruyter. Translated as, Man in the Modern Age, trans. E. Paul and C. Paul (London: Routledge, 1933). The original volume in German came out in 1931.
} 
when Nazi ideology and institutional practices were beginning to run rampant in Germany. This work constitutes the departure point for the next section of the present debate on collective responsibility.

Jaspers' contribution to the literature on collective responsibility took an even more pointed form with the publication of the Die Schuldfrage [The Guilt Question], which addressed the question of the collective responsibility for the German people for the criminal actions of their government. ${ }^{38}$ In that short treatise, Jaspers listed four types of guilt. The first category, criminal guilt, derives from violating unequivocal laws and is capable of being determined based on objective proof. Its jurisdiction rests with the courts. The second category, political guilt, involves the deeds of statesmen and implicates the citizens of a state for having to bear the consequences of the deeds of the state whose power governs them and under whose order they live. Jurisdiction of this type of guilt rests with the power and will of the victor if the state was defeated militarily, or, again with the courts if this was a civil war situation. The failure to exercise political prudence to mitigate arbitrary use of power would be the charge. Then, there is the category of the moral guilt. It pertains to the actions of those who cannot act otherwise than as an individual. They are nonetheless deemed as morally responsible for all their deeds, including the execution of political and military orders. This text was written prior to Nuremberg and Eichmann Trials and Jaspers posited back than that its jurisdiction purely rests with one's conscience, is retained within the community. Jaspers' last category, that of metaphysical guilt, is the most troubling one and it also became a point of contention in his lengthy exchanges with Arendt during the post-War years. Accordingly, Jaspers assumes that there exists a solidarity among men as humans that makes each co-responsible for crimes committed in his presence or with his knowledge.

This last point definitely merits further consideration in the context of collective responsibility debates. No doubt, its underlying assumption can easily lead to sanctimonious political moralism that has often been used to justify acts of vengeance and collective punishment. It may also lead to a conception of war as a crusade that requires unconditional surrender by the enemy and lead to unnecessary harm. ${ }^{39}$ For Jaspers metaphysical guilt results from confining our solidarity to the closest human ties -- family, friends, neighbors, ethno-religious

\footnotetext{
${ }^{38}$ See the English trasnlations as Karl Jaspers, The question of German guilt (Fordham University Press, 2009). This work was translated by E. B. Ashton and it was published in a series edited by John Caputo. The original version came out in German back in 1946 and the first English edition was published in 1947. See Karl Jaspers, Die Schuldfrage, Heidelberg: Schneider ([translated as, The Question of German Guilt, trans. E. B. Ashton] The Dial Press, 1947).

${ }^{39}$ See Hannah Arendt, et al. "Hannah Arendt/Karl Jaspers Correspondence, 1926-1969." (Harcourt Brace Jonakovich, 1992).
} 
brethren, etc. - rather than extending it to all of humanity. It makes us suffer from lack of proportion in terms of judging our world and human value. In the end, Jaspers himself acknowledges that jurisdiction over metaphysical guilt lies with no court. Still, this easily abused concept reminds us of the myriad ways in which our lives are entangled with and may profit from the suffering of others.

\section{COLLECTIVE RESPONSIBILITY AND LEGAL JUDGMENT IN INTERNATIONAL LAW: THE JASPERS ALTERNATIVE?}

Ascertaining litigation for crimes reaching the dimensions of what Jaspers had in mind is an elusive quest. This is despite the precedents set by post-WWII trials. Indeed, the trial of major Nazi war criminals in Nuremberg (1949) is considered a landmark event in the development of modern international law, and continues to be highly influential in our understanding of international criminal law and post-conflict justice. ${ }^{40}$ The plethora of essays and manuscripts written on the Trial, discussing key legal, political, and philosophical questions raised by the Trial both at the time and in historical perspective, are indicative of the crowned position the Trial occupies in legal history. Those involved in the Tribunal, the establishment of the Tribunal, the Trial process itself, and the debate that followed its' judgment have all been subject to rigorous academic debate. Ranging from the contribution of Nuremberg to the substantive development of international criminal law, to the philosophical evaluation of legalism in post-conflict systems of justice, the persistent significance of Nuremberg is indeed worthy of attention across a range of academic disciplines. ${ }^{41}$ Examinations of the Nuremberg legacy in contemporary international criminal justice are already widely available. The reason why I include a discussion on the Nuremberg Trials in this article on collective responsibility is for a somewhat different reason. Nuremberg Judgment is often counted as the benchmark in international law for the definition and adjudication of individual accountability for human rights abuses at a mass scale. In this sense, it did constitute a turning point in the context of legal doctrines concerning the nature of legal responsibility. However, as I will argue in the following paragraphs, this achievement did not alleviate Jaspers' concern that for such crimes, the judgment cannot emanate from the courtroom alone.

\footnotetext{
${ }^{40}$ See Diane F. Orentlicher, "Settling accounts: the duty to prosecute human rights violations of a prior regime" (1991) 100 Yale Law Journal 2537; Steven Ratner, Steven, Jason S. Abrams \& James L. Bischoff Accountability for Human Rights Atrocities in International Law: Beyond the Nuremberg Legacy (Oxford University Press, 2009).

${ }^{41}$ See Henry T. King Jr, “The Legacy of Nuremberg” (2002) 34 Case W. Res. J. Int'l L. 335; Christian Tomuschat, "The legacy of Nuremberg" (2006) 4 Journal of International Criminal Justice 830, and, Steven R. Ratner, Jason S. Abrams \& James L. Bischoff. Accountability for human rights atrocities in international law: beyond the Nuremberg legacy (Oxford University Press, 2009).
} 
During the Trial, the concept of Nullum Crimen Sine Lege has been put to the test of war crimes and despite a degree of inexactitude, both crimes against humanity and genocide have been retroactively codified as a result. These developments in adjudication of international crimes were then followed by the codification of slavery, forced labor, torture, forced disappearances, racial discrimination and apartheid as indictable crimes. In this sense, the Trial also redefined the notion of culpability in international law. It introduced significant changes in our understanding of individual criminal responsibility and despite statutes of limitations and the 'reasonable time period' clauses, it opened the path for reinstituting the threshold of legal requirements for individual accountability for mass crimes. Aside from its importance concerning the codification of societal and mass crimes in international law, however, Nuremberg Trial also forced us to address the problem of whether and on what basis a successor government must prosecute the human rights abuses of a prior regime. Contending that the rule of law and natural justice principles require that the very worst crimes be prosecuted no matter what the rank and status of the accused person(s) may be, Nuremberg judges proposed that principles of international law, both in its customary and conventional forms, impose a duty to investigate and prosecute in such extreme cases. ${ }^{42}$ This take on legality and judgment was then accepted as a foundational premise for future international courts. ${ }^{43}$ However, in terms of defenses available for the accused in international criminal law pertaining to war crimes and crimes against humanity, for instance, the generic standardization of prosecutions in national courts as well as in international tribunals is causing increasing number problems with significant socio-political repercussions. The most important substantive defenses include superior orders, command responsibility, tu quoque as a subcategory of argumentum ad hominem, military necessity, proportionality, and reprisals. Jurisdictional defenses applicable in national tribunals include personal jurisdiction, subject-matter jurisdiction, and double jeopardy. Then there is the issue of the location of the tribunal or the trial, the status of the presiding judge or judges and the legitimacy of the court producing the judgment. ${ }^{44}$

\footnotetext{
${ }^{42}$ See Aryeh Neier War crimes: Brutality, genocide, terror, and the struggle for justice. (Crown Publishing Group,1998).

${ }^{43}$ See Cherif M. Bassiouni, ed. International Criminal Law, Volume 2 Multilateral and Bilateral Enforcement Mechanisms (Brill, 2008); William Schabas, An Introduction to the International Criminal Court (Cambridge University Press, 2011) and the standard text book by Antonio Cassese, Paola Gaeta, Laurel Baig, Mary Fan, and Christopher Gosnell, Cassese's international criminal law (Oxford University Press, 2013).

${ }^{44}$ James Meernik, "Victor's Justice or the Law? Judging And Punishing At The International Criminal Tribunal For The Former Yugoslavia" (2003) 47 Journal of Conflict Resolution 140; Victor Peskin, "Beyond Victor's Justice? The Challenge of Prosecuting the Winners at the International Crimi-
} 
Furthremore, if we look at the victor's justice argument posed about Nuremberg and Tokto trials from the point of view of the victims, it is possible to posit that although forgiveness is often taken to bear a close connection to societal reconciliation, there is a good deal of scepticism about its role in situations where there is no consensus on the moral complexion of the past and no clear admission of guilt on the part of the perpetrator. In other words, the conviction-oriented framework of these post-WWII Military Tribunals are indeed troubling for societal and political crimes. Forgiveness without perpetrator acknowledgement aggravates the risk of recidivism, yields a substandard and morally compromised form of political accommodation, and leads to the silencing and patronizing of the victims, therefore potentially causing further social and political alienation ad victimization. Guilt becomes inscribed to the collective memory of nations as a dividing line, but neither forgiveness nor true understanding emanates from litigation of such crimes alone.

\section{MORAL RESPONSIBILITY AS AN EPICURIAN CURE FOR THE CONUNDRUMS OF INTERNATIONAL CRIMINAL LAW?}

From Epicurus onwards, the notion of moral responsibility based on a moral agent's causal ownership of his/her actions, as opposed to the agent's ability to act or choose otherwise, has troubled legal thinking. This is indeed the crux of the matter that Frankfurt examples were built upon. It also relates to the puzzles surrounding Arendt's take on the banality of evil and the possibility/impossibility of the punishment of the unforgiveable. Epicurus considered it a necessary condition for praising or blaming an agent for an action, that it was the agent and not something else that brought the action about. ${ }^{45}$ Thus, the central question of moral responsibility was whether the agent was a cause of the action, or whether the moral agent was forced to act by some other force. Accordingly, actions are

nal Tribunals for the Former Yugoslavia and Rwanda" (2005) 4 Journal of Human Rights 213; Bill Wringe, "Why punish war crimes? Victor's justice and expressive justifications of punishment" (2006) 25 Law and Philosophy 159; William A. Schabas, "Victor's Justice: Selecting Situations at the International Criminal Court" (2009) 43 J. Marshall L. Rev. 535.

${ }^{45}$ See Epicurus, The Essential Epicurus: Letters, Principal Doctrines, Vatican Sayings, and Fragments (Prometheus Books, 1993) This popular arrangement of fragments follows the outline set forth by C. Bailey's 1926 collection on the thinker. One of the major philosophers in the Hellenistic period [the three centuries following the death of Aristotle in 323 B.C.E.], Epicurus developed an unsparingly materialistic and empiricist epistemology, and is known for his hedonistic ethics. He rejected the existence of Platonic forms and an immaterial soul, and famously declared that gods have no influence on our lives. His' gospel of freedom from fear proved to be quite popular, and communities of Epicureans flourished for centuries after his death. In Anglo-American philosophical traditions, Epicurean thought re-emerged primarily in the context of moral responsibility and intentionality. See Phillip Mitsis, Epicurus' Ethical Theory: The Pleasures of Invulnerability (Cornell University Press, 1988). 
to be attributed to moral agents because it is in their actions that the agents, qua moral beings, manifest themselves. In this context, the question of moral engagement becomes all the more important. ${ }^{46}$ In his narration concerning how humans become moral beings, Epicurus envisaged a complex theory of moral responsibility and moral development, which could indeed find application in the area of collective responsibility and mass crimes. Epicurean ethics does not have the function of developing or justifying a moral system that allows for the effective allocation of praise and blame. ${ }^{47}$ Instead, it looks at the choices people make regardless of the system they are surrounded by. On the issue of free will and moral responsibility, Harry Frankfurt's argument that moral responsibility does not require the freedom to do otherwise, linked with the debate over whether moral responsibility is an essentially historical concept, indeed echoes the Epicurean call for deciphering individual agency in collective acts. Thus, the central question of moral responsibility becomes whether the agent was the cause of the action, or whether the agent was forced to act.

Some instances of wrongdoing are distinctly of a collective kind. When, for example, one group commits genocide against another, this is a collective act of crime in the sense that the wrongness of genocide is morally distinct from the aggregation of individual murders that make up the genocide. The problem, which I will refer to as the problem of collective wrongs, is that in traditional criminal law, how to assign blame for distinctly collective wrongdoing to individual contributors when at least some of those individual contributors are not directly guilty of the wrongdoing in question is habitually left unclear. I already offered Christopher Kutz's Complicity Principle as a starting point for solving this particular problem, although the principle ought to be expanded to include a broader and more appropriate range of cases than Kutz initially intended. The

\footnotetext{
${ }^{46}$ Developing a core conception of moral responsibility, Epicurus' writings pose the question of what human life without moral responsibility would be like. That exploration alone establishes that many robust forms of human relationship and situational normativity could continue, absent moral responsibility. However, accountability would become impossible. For a full debate on the Epicurean legacy concerning contemporary debates on moral responsibility, see Martin John Fischer, My Way: Essays on Moral Responsibility (Oxford University Press, 2006). Fischer's work is particularly relevant in its emphasis on the connections between deliberation and action, and, between free will, freedom of action, and moral responsibility/accountability. This frame of reference ties together responsibility for actions, omissions and consequences.

${ }^{47}$ On the issue of the allocation of moral responsibility to individuals in complex collective wrongdoings, see Kenton Machina, "Moral Responsibility-What is All the Fuss About?" (2007) 22 Acta Analytica 29; Neil Levy \& Michael McKenna "Recent Work on Free Will and Moral Responsibility" (2009) 4 Philosophy Compass 96, and, M. Braham \& M. van Hees "An Anatomy of Moral Responsibility" (2012) 121 Mind 601. Braham and van Hees' work is particularly significant for the examination of the structure of moral responsibility in relation to outcomes. A central feature of their analysis is a condition that they term as the 'avoidance potential', which indicates that moral responsibility implies a reasonable demand that an agent should have acted otherwise.
} 
view I ultimately defend is that individuals are blameworthy for collective harms insofar as they knowingly participate in or collaborate in the committal of those harms, and that said individuals remain blameworthy regardless of whether they succeed in making a causal contribution to those harms. ${ }^{48}$

Another prominent political philosopher of the post-WWII era, Michael Bratman also made critical contributions to our understanding of the notion of intention and how it relates to action, in particular criminal action. In Bratman's view, when we settle on a plan for action we are committing ourselves to future conduct. The commitment involved in intending, and its implications for our understanding of shared intention and shared cooperative activity, lead to a rich discussion on moral responsibility. ${ }^{49}$ In the context of philosophy of action and moral philosophy, issues about the nature of agency, intention and practical reason, free will and moral responsibility, and shared agency are indeed much more easily brought to the fore compared to the difficulties we may face with regard to discussing these in the context of philosophy of law. In this sense, Bratman's work Intention, Plans, and Practical Reason (1987) permanently altered the landscape of both the philosophy of action and the theory of practical rationality, by drawing our attention to the complex, constitutive roles that intention plays in human agency. ${ }^{50}$ In particular, his essays on shared agency are of utmost significance for the debate on collective responsibility. ${ }^{51}$

If we accept Bratman's description, the notion of collective responsibility would refer to both the causal responsibility of moral agents for harm in the world and the blameworthiness that we ascribe to them for having caused such harm. Hence, it would assume both a moral and a causal component. Criminal law associates causal responsibility and blameworthiness with groups only in rare cases such as

\footnotetext{
${ }^{48}$ On this issue, also see Brian Lawson, "Individual Complicity in Collective Wrongdoing" (2013) 16 Ethical Theory and Moral Practice 227.

${ }^{49}$ See Michael Bratman, Faces of intention: Selected essays on intention and agency (Cambridge University Press, 1999)

${ }^{50}$ What happens to our conception of the mind and of rational agency when we take future-directed intentions seriously? What is the role of intention as input for practical reasoning? Michael Bratman responded to these questions in a series of papers that he wrote during the early 1980s. In his manuscript Intention, Plans, and Practical Reason, Bratman fully developed the main themes of the previous essays and proposed a full-fledged theory of intention. In this later work, intentions are treated as essential elements of plans of action. These plans play a basic role in practical reasoning, supporting the organization of our activities within a future oriented trajectory. Bratman's work also explores the relationship between intention and intentional action, as well as the distinction between intended and expected effects of what one intends. All these issues are very critical for reaching a deeper understanding of collective responsibility. See Michael Bratman, Intention, Plans, and Practical Reason (University of Chicago Press, 1987).

${ }^{51}$ Michael Bratman, Shared agency: A planning theory of acting together (Oxford University Press, 2013).
} 
genocide and crimes against humanity, but for litigation purposes the line in the sand is always drawn at individual culpability. Criminal jurisprudence locates the source of moral responsibility in collective actions only if collectives were directly involved in these acts of harm. ${ }^{52}$ Here, I beg to differ from this commonplace referral to the notion of collective responsibility as derivative of an assumed group morality. I am also standing against the assumption that collective responsibility violates principles of individual responsibility and fairness concerning criminal attribution. On the contrary, I propose that collective responsibility-as well as group intentions, collective action, and group blameworthiness-is a coherent construct and can be ascribed to moral agents fairly in cases of societal and political crimes. This attribution, however, does not have to be punitive in nature.

My reservations about associating collective responsibility with group morality could perhaps be explicated in the context of the structure of the argument that was augmented by traditions of religious thought such as those found in the Old Testament (Tanakh) referring to the accounts of the Flood, the Tower of Babel or Sodom and Gomorrah as well as the New Testament blaming of Jews as an entire race for the killing of Jesus Christ. In these narratives, entire communities were punished for their supposed deeds and to set an example for the rest of humanity. In Biblical narratives pertaining to the death of Jesus, for instance, the blame was cast not only on the Jews of the time but upon all future generations to come. The core of these religious arguments relates to a desire for communal forms of punishment for collective harms. No doubt, secular forms of this logic are equally widespread and troubling. Post 9/11 trends of anti-Islamism and resultant public policy measures are a case in point that is all too familiar. Collective responsibility translated into a rationale for collective punishment is also regularly used as a disciplinary measure in military units, prisons, and psychiatric facilities used for political crimes such as those operated in Russia. ${ }^{53}$ Without fail, these measures breed distrust and desire for vengeance among the members of the punished group and their communities at large. These punishment schemes are also commonly practiced in situation of war based on the presupposition of collective guilt. Collective guilt, or guilt by association, is a dangerous claim that assumes groups of humans can bear guilt above and beyond the guilt of individual members. Contemporary criminal law operates on the principle that guilt shall only be attributed to a legal person and not to a group or community. Keeping these intricacies and problem-laden

\footnotetext{
${ }^{52}$ For a debate on intergenerational collective responsibility, see Janna Thompson, (2006) "Collective Responsibility for Historic Injustices" (2006) 30 Midwest Studies in Philosophy 154.

${ }^{53}$ See Melvyn Freeman \& Soumitra Pathare. WHO resource book on mental health, human rights and legislation (World Health Organization, 2005) and Steven Fish, Democracy derailed in Russia: The failure of open politics (Cambridge University Press, 2005).
} 
historical examples of attribution of collective guilt in mind, one must not equate collective responsibility either with collective punishment or collective assignment of presumed moral failure to groups, communities or societies. However, this precaution should not refrain us from seeking a substantive definition of collective responsibility for mass crimes.

While the majority of debates on collective responsibility continue to deliberate on the very possibility of it, a select group of scholars ushered in two further concerns. The first has to do with whether groups could meet stringent conditions of moral responsibility that individuals do. Intentionality, as I touched upon briefly in the above paragraphs, becomes key in this context. The second concern has to do with the advantages and disadvantages of holding particular kinds of groups such as communities or particular ethno-religious groups, or even states, morally responsible in response to harm caused by their direct or indirect actions. ${ }^{54}$ One key example to consider in this area is that of lustration. Often, after a regime-changing war, a state engages in lustration in order to secure the condemnation and punishment of dangerous, corrupt, or culpable members of the previous political system. Changes in the political structure of postApartheid South Africa, post-WWII de-Nazification of Germany or the recent deBa'athification in Iraq are commonly referred cases of lustration. This common practice poses an important dilemma from the perspective of how to define and put into practice collective responsibility because even well planned, legally sound and nuanced lustration involves condemning groups of people. ${ }^{55}$ It also raises important questions about collective agency and rectification of historical injustices. While group treatment might be justified on grounds of convenience and political peace in times of transitional justice, there are also valid arguments consistent with due process requirements for wholesale group punishment. ${ }^{56}$

\footnotetext{
${ }^{54}$ For instance, the proxy wars in Iraq and Afghanistan have put front and center the problem of dealing with non-uniformed combatants. They also led to questions concerning the legitimacy of resorting to martial violence under such circumstances of quasi occupations. The location of the legal agency for attributing responsibility for righting the wrongs committed afterwards and who to turn to for that end remain as major issues, especially for the American military establishment. The specific problem of non-uniformed combatants and the general problem of justifying war are profoundly linked. War is but only one form of generalized collective violence. Collective violence poses a particular set of challenges to the application of moral and legal principles within the context of the traditional model of criminal responsibility. See Anna Stilz, "Collective responsibility and the state" (2011) 19 Journal of Political Philosophy 190, and, Christopher Kutz, "The difference uniforms make: collective violence in criminal law and war" (2015) 33 Philosophy \& Public Affairs 148.

${ }^{55}$ This problem is discussed in detail in Avia Pasternak, "The collective responsibility of democratic publics" (2011) 41 Canadian Journal of Philosophy 99. The main reference used in this context is Hanna Pitkin's work. See Hanna Fenichel Pitkin, The Concept of Representation (University of California Press, 1967).

${ }^{56}$ See Yvonne Chiu, "Liberal Lustration" (2011) 19 Journal of Political Philosophy 440. For a larger debate on war and justice, see Robert E. Williams \& Dan Caldwell, "Jus post bellum: Just war theory
} 
Concomitantly, I would like posit a theory of combined criminal and political accountability based on an understanding of collective action and collective responsibility that not only allows for but demands individual responsibility. ${ }^{57}$ In other words, instead of generalizing the sum total of individuals as a collective, the causation I propose implicates a movement from the collective back to the individual. No doubt, there isn't a single, simple and all-encompassing solution to the problem of the relationship between individual and collective responsibility for wrongdoing and harm. The one component that obscures the fundamental requirement for responsibility ascriptions most is that of moral agency. Closer attention to matters of individual and collective agency may provide a defensible criterion for establishing when an individual is and isn't responsible for the untoward consequences of a collective act. ${ }^{58}$ For instance, not only individuals but organizations and institutions can act and exercise power and thus could be deemed as accountable for harm. This is possible because they possess decisionmaking structures that are formal. As such, they could be deemed as 'legal persons'. The actions of such legal actors are not reducible to the actions of its individual members. Since these legal actors/agents could have acted differently or could have been re-organized to change the course of their harmful acts, they could be deemed as morally responsible for the untoward effects of the power they exercise to the larger population. Thus, at least in principle, they are blameworthy and could be subject to legal judgments. The ability to exercise power purposely, knowingly as opposed to recklessly, or negligently, reveal a particular disposition to abusing power since it is concentrated and institutionalized. Furthermore, I would argue that such legal actors' disposition is not reducible to the dispositions or degrees of

and the principles of just peace" (2006) 7 International Studies Perspectives 309; Jens Meierhenrich, «The ethics of lustration» (2006) 20 Ethics \& International Affairs 99; Darrel Mollendorf, "Jus ex bello" (2008) 16 Journal of Political Philosophy 123; Mark Evans, «Moral responsibilities and the conflicting demands of jus post bellum»(2009) 23 Ethics \& International Affairs 147; Anatoly Levshin, «Jus Contra Bellum in the Modern States System: Observations on the Anomalous Origins of the Crime of Aggressive War» (2015) 10 St Antony's International Review 141.

${ }^{57}$ See Christopher Kutz, Complicity: Ethics and Law for a Collective Age (Cambridge University Press, 2007)

${ }^{58}$ Albert Flores \& Deborah G. Johnson, "Collective responsibility and professional roles" (1983) 93 Ethics 537. This is a very interesting debate on the responsibilities of 'the peg in the cog', i.e. individuals working as part of large institutions and organization and towards a cumulative end result. The authors reach the conclusion that collective responsibility cannot be appropriated to individuals in such situations. Rather, it should be the specific individuals and offices that provide the overall design and goals of the organization and determine the distribution of duties that should be held responsible from erroneous acts of such organized bodies. For a counter argument on this issue, see W. H. Walsh, "Pride, shame and responsibility" (1970) 20 The Philosophical Quarterly 1. Also see Virginia Held, “Can a random collection of individuals be morally responsible?" (1970) 67 Journal of Philosophy 471. For Held, the crux of the matter lies at the defining characteristics of a 'collectivity' and how they reach decisions that lead to harm. She takes a strong position against 'methodological individualism', which I share full-heartedly. 
blame of the individual members who participated in the internal decision-making processes or even those who led these organizations and institutions. Instead, there is a need for a larger discussion on the interdependent relationship between the individual and the collective in upholding a system of abuse, harm and danger. Here, the Epicurean cure for the conundrums of the debate on moral responsibility comes to our rescue as the foreground allowing us to think about intentionality and causal involvement in collective acts, and as a call for assuming responsibility for our own decisions to act or not to act.

\section{COLLECTIVE RESPONSIBILITY AND THE DISTRIBUTION OF BLAMEWORTHINESS}

Whether collective responsibility makes sense as a non-distributive phenomenon, that is to say whether it transcends the contributions of particular group members, is a debate that remains pivotal for legal theory. In this context, two claims are crucial. The first is that groups, unlike individuals, cannot be accountable for intentions and hence cannot act or cause harm qua groups. The second is that groups, as distinct from their individual members, cannot be understood as morally blameworthy according to the criteria required by moral responsibility argument. Accordingly, we cannot isolate genuinely collective actions, as distinct from identical actions of many persons, and groups, unlike the individuals who belong to them, cannot formulate intentions of the kind thought to be necessary to actions. Here, the main worry is about the fairness of ascribing collective responsibility to individuals who do not themselves directly cause harm or who do not bring about harm purposefully. ${ }^{59}$

If group intention is a necessary condition of attributing collective responsibility, the question then becomes how to ascertain it. ${ }^{60}$ In this context, collective behaviors are separated from collective actions, the latter arguably caused by the beliefs, desires and wants of the collective itself. As such, moral

\footnotetext{
${ }^{59}$ See Steven Sverdlik, "Collective Responsibility” (1987) 51 Philosophical Studies 61. For him, moral blameworthiness requires the existence of bad intentions - or at least moral faultiness-on the part of those being held responsible. Otherwise, one cannot seek criminality. On this issue, also see Seumas Miller, "Collective responsibility" (2001) 15 Public Affairs Quarterly 65 and Jan Narveson, "Collective responsibility" (2002) 6 The Journal of Ethics 179. Miller's emphasis is typical of the traditional criminal law take on collective responsibility. He underlines joint actions rather than omissions and complicity that cause grave harm. He also makes a clear distinction between retrospective and prospective responsibility, an issue best attended in the context of debates on restorative justice.

${ }^{60}$ See Angelo J. Corlett, Responsibility and Punishment. Vol. 9. (Springer, 2009). For Corlett, collective intentionality is a required condition to ascertain collective liability. In this vein, he also argues that collective responsibility could only be ascertained if there was collective voluntariness and if we could identify a corporate moral agency for wrongdoing and harm.
} 
blameworthiness is grounded in the bad intentions of moral agents who cause harm in defining both individual and collective responsibility. If so, how groups, as distinct from their individual members, could have bad intentions and demonstrate the ability to act on them? Could entire communities be deemed as appropriate bearers of moral blameworthiness, guilt, or shame? Critics of the collective responsibility argument concentrate on showing either that, actions are associated exclusively with individuals, not groups or communities, or that groups cannot make choices or hold beliefs in the sense required by the formulation of intentions as defined by criminal law. ${ }^{61}$ Meanwhile, these same critics pay much less attention to the nature of collective actions. It may be true that collectivities may not have moral faults, since they don't make moral choices in the way that is commonly understood. And yet, does that by default mean they cannot properly be ascribed moral responsibility for their harmful actions that are only possible if and when individuals act collectively?

At the other end of the spectrum, defenders of collective responsibility argument feel propelled to justify both the moral possibility of collective responsibility and the coherence of collective responsibility as a moral, and hence possibly legal, construct. To start with, precepts of methodological individualism are brought under attack. ${ }^{62}$ Accordingly, the collective blame that we ascribe in mass crimes cannot be realized in terms of individual blameworthiness. Furthermore, as exemplified by Larry May's work, there is a class of predicates that can only be true of collectives. May uses the relational theory of JeanPaul Sartre to argue that groups can legitimately be ascribed actions in cases where individuals act together in a manner that would not be possible if they acted alone. ${ }^{63}$ On the issue of group intentions, however, the legal problem of ascertaining intentionality is not easy to tackle and it remains a threshold issue for criminal law related determinations. If intentions play a fundamental role in an agent's practical deliberation and volition, the prospect of a shared intention introduces the specter of shared mental states. That is not included in the standards of proof for criminal law litigation.

\footnotetext{
${ }^{61}$ See, for instance, the classical work of Hywel D. Lewis, "Collective responsibility" (1948) 23 Philosophy 3 as well as David E. Cooper, "Collective responsibility" (1968) 43 Philosophy 258, and Robert Silcock Downie, "Collective responsibility" (1969) 44 Philosophy 66.

${ }^{62}$ See David E. Cooper, "Collective Responsibility” (1968) 43 Philosophy 258 and Howard McGary, "Morality and Collective Liability" (1986) 20 The Journal of Value Inquiry 157. Peter French's work on corporations is particularly useful in this context. See Peter A. French, "The Corporation as a Moral Person" (1979) 16 American Philosophical Quarterly 207. Interestingly, this debate dates back to late 1970s, way before the post-Marxist legal critiques of international public law.

${ }^{63}$ See Larry May The Morality of Groups (University of Notre Dame Press, 1989) and Larry May \& Stacey Hoffman, eds. Collective Responsibility: Five Decades of Debate in Theoretical and Applied Ethics (Rowman \& Littlefield Publishers, 1992)
} 
In other words, if the possibility of collective responsibility supposedly requires a collective mind, we might as well give up on the notion of collective responsibility altogether. Groups can legitimately be said to have shared beliefs and convictions. And yet, this is quite distinct from the proposition of a collective mind-set. These convictions are otherwise known as institutional culture, ideology, political movements etc. Hence, looking for a collective mind-set for ascertaining collective responsibility for societal harm and wrongdoings is not the business of criminal justice litigation. ${ }^{64}$ In Raimo Tuomela and Kaarlo Miller's work, these factors are named as 'we intentions' and they provide the springboard for joint commitments and actions. ${ }^{65}$ Furthermore, according to Tuomela, actions by collectives build upon the actions of the operative members of the collective in such a way that the properties of collectives, such as their intentions, beliefs, and desires, are both embodied and determined by the perspectives of individual members or representatives of the collective in question. This is an unusual intervention with very important implications for the production of legal judgments concerning collective wrongs. Indeed, May offers one of the most interesting arguments of this sort in his defense of collective moral agency. Although he rejects accounts of group intentions that are tied to Kantian notions of moral agency, he reformulates group intentions with reference to a theory of interdependence and sociality.

Historically, for those who work on collective responsibility as a necessary notion for applied philosophy, ethics, and legal theory, the focus has been on nations, corporations, and other groups that have an institutional backbone and well-ordered decision-making procedures in place. Organizational and institutional mechanisms through which courses of concerted action have been decided upon and justified as rule-bound are deemed particularly important. Similarly, enforced standards of conduct for individuals that are stringent and disciplinarian constitute an important aspect of such forms of action. In turn, purposeful, planned and institutionally controlled actions could render groups

\footnotetext{
${ }^{64}$ According to both Margaret Gilbert and Michael Bratman, the keyword is joint commitment. In other words, group intentions exist when two or more persons constitute the plural subject of an intention to carry out a particular action. See Margaret Gilbert "Modelling collective belief" (1987) 73 Synthese 185; Margaret Gilbert, Living together: Rationality, sociality, and obligation (Rowman \& Littlefield Publishers, 1996); Margaret Gilbert, Sociality and responsibility: New essays in plural subject theory (Rowman \& Littlefield Publishers, 2000); Margaret Gilbert "Shared intention and personal intentions" (2009) 144 Philosophical studies 167. Bratman's most relevant work in the context of shared intention and mutual obligations is his Faces of intention: Selected essays on intention and agency (Cambridge University Press, 1999). Also see David J. Velleman, J. David "What happens when someone acts?" (1992) 101 Mind 461.

${ }^{65}$ See Raimo Tuomela \& Kaarlo Miller "We-intentions” (1988) 53 Philosophical Studies 367. Also see Raimo Tuomela, "We-intentions revisited" (2005) 125 Philosophical Studies 327 and Raimo Tuomela, The Philosophy of Sociality: The Shared Point of View (Oxford University Press, 2007).
} 
and communities collectively responsible for harm caused by their joint acts, though most likely not in a criminal sense. In the case of social and political movements, as discussed in detail by Joel Feinberg and his body of work on collective responsibility, there is the added element of ideological directives and resultant group solidarity leading individuals to pursue projects together as a collective agent. ${ }^{66}$ All of these are aspects of a very germane debate on collective responsibility that has been thus far overlooked by theories of international criminal law pertaining to mass crimes, war crimes, and crimes against humanity. This is a deep chasm that must be addressed without further ado, if not directly in the area of criminal law then in legal theory pertaining to criminal law.

\section{CONCLUSION: THE DILEMMA OF THE SUM TOTAL VERSUS ITS CONSTITUTIVE PARTS}

Since collective responsibility refers to the addressing of widespread harm and wrongdoing associated with the actions of collectivities, groups, societies and institutional bodies, the key components of its adjudication are directly related to constitutive aspects of social, cultural and political life in general. While there is a broad, often tacit, agreement regarding the basic model of moral and criminal responsibility when it is applied to individuals, as we have seen thus far, there is considerable moral and legal doubt about how this notion might be applied to collectivities and their members at large. First and foremost, adjudication of collective responsibility leads to a disagreement about the very conception of collective responsibility.67 One version maintains that only individual human agents can be held morally and criminally responsible for harmful acts, and while another conceptions insists that groups, collectivities and institutions can be held morally and criminally responsible as collectivities, independently of their members' individual actions. The former conception has, as its departure

\footnotetext{
${ }^{66}$ See Joel Feinberg, Doing and Deserving; Essays in the Theory of Responsibility (Princeton University Press, 1970). In his later treatise Moral Limits of Criminal Law, Feinberg focuses on the relationship between interests and wants, and makes a distinction between want-regarding and ideal-regarding analyses of interests. In particular, he focuses on hard cases for the applications of the concept of harm. Examples of the "hard cases" Feinberg uses are harm to character, vicarious harm, and prenatal and posthumous harm. Feinberg also discusses the relationship between harm and rights, the concept of a victim, and the distinctions of various quantitative dimensions of harm, consent, and offense, including the magnitude, probability, risk, as well as the importance of harm for both the individual and the society at large. See Joel Feinberg, The Moral Limits of the Criminal Law (Oxford University Press, 1984).

${ }^{67}$ The main texts I refer to in this regard are again those pertaining to the Arendt-Jaspers correspondence. Also see Hannah Arendt, German guilt (Jewish Frontier Association, 1945); Karl Jaspers, The question of German guilt (Fordham University Press, 2009) and his The Origin and Goal of History (Routledge Revivals Series, Routledge, 2014).
} 
point, the conviction that collectivities and institutions are capable of actions that cannot be reduced to the actions and interests of their individual members. ${ }^{68}$ And yet, this belief or conviction alone does not render adjudication of collective responsibility a straightforward process.

In this context, Joel Feinberg's taxonomy of collective responsibility arrangements constitutes a critical contribution to the exploration of issues regarding the culpability of collectives and their members. In his classical treatise written back in 1970, Doing and Deserving, Feinberg presents four distinct responsibility arrangements: (a) "Whole groups can be held liable even though not all of their members are at fault..." (b) "A group can be held collectively responsible through the fault, contributory or noncontributory, of each member" (c) "Group liability [could be attributed] through the contributory faults of each and every member" and (d) "Through the collective...fault of the group itself [the collective] bears liability independently of its members." ${ }^{69}$ If we are to consider each of Feinberg's constructs in order to reach a conclusion pertaining to the justiciability of collective acts leading to harm, the following complications need to be adequately addressed..$^{70}$

\begin{abstract}
${ }^{68}$ See Carl Wellman, $A$ Theory of Rights: Persons under Laws, Institutions and Morals (Rowman \& Allanheld, 1985); Meir Dan-Cohen, Rights, Persons, and Organizations a Legal Theory for Bureaucratic Society (University of California Press, 1986) and Allen Buchanan, "Toward a Theory of the Ethics of Bureaucratic Organizations" (1996) 6 Business Ethics Quarterly 419. These essays articulate a crucial and neglected element of pertaining to the general theory of ethics of bureaucratic organizations, in both private and public realms. The key to the approach developed here is the thesis that distinctive ethical principles must be applicable to bureaucratic organizations due to their aggregate powerholding status. This arises from the nature of bureaucratic organizations as complex webs of principal/agent relations that cannot be reduced to individual actions within that realm.

${ }^{69}$ In his treatise Doing and Deserving, Feinberg covers the following notions that are most pertinent to the current debate on collective responsibility: Supererogation and rules, problematic responsibility in law and morals, justice and personal desert, sua culpa and collective responsibility. See Joel Feinberg, Essays in the Theory of Responsibility (Princeton University Press, 1970). Also see his The Moral Limits of the Criminal Law (Oxford University Press, 1984). This latter work is the first volume in a fourvolume series entitled The Moral Limits of the Criminal Law that addresses the question of what acts the state may rightly render as criminal. Here, Feinberg identifies four liberty-limiting or coercionlegitimizing principles, each of which is the subject of a separate volume. In the first volume on the Moral Limits, he looks at the principle of harm to others, which John Stuart Mill identified as the only liberty-limiting principle. The other principles that Feinberg considers in subsequent volumes are (1) the offense principle--it is necessary to prevent hurt or offense (as opposed to harm) to others; (2) legal paternalism--it is necessary to prevent harm to the actor herself; and (3) legal moralism--it is necessary to prevent immoral conduct whether or not it harms anyone. Feinberg himself rejects legal paternalism and legal moralism, maintaining that the harm principle and the offense principle exhaust the class of morally relevant reasons for criminal prohibitions. Feinberg's examination of the harm principle begins with an account of the concept of harm and its relation to other concepts like interests, wants, hurts, offenses, rights, and consent. He considers both the moral status of a failure to prevent harm and the problems related to assessing, comparing, and imputing harms. These discussions are essential for developing a robust legally applicable understanding of collective responsibility.
\end{abstract}

${ }^{70}$ Justiciability is a key concept especially for constitutional and international law due to the fact 
In Feinberg's first case, if a whole group is liable for the faulty and harmful actions of one or several members of the group, there must be the accompanying assumption that this sort of collectivity possesses a significant degree of solidarity. No doubt, this presumption stands against the ideal of individual responsibility and autonomy. Punishment of all for the wrongdoing of a few is not customarily defensible on moral or legal grounds. For both goods and harms to be defined as collective and shared, would promotion of a mutual sense of collective destiny suffice? Looked at through the lens of justiciability, the answer is negative. Courts often invoke one of the justiciability doctrines - standing, ripeness, and mootness to bring potentially important public litigation to a definite conclusion. According to orthodox understanding of justiciability, these doctrines disempower courts from deciding certain kinds of cases. Of the three, mootness doctrine is the most relevant for our purposes as it has the strongest moral moorings in terms of law's compass in society. Collectives are not punishable where individual autonomy is held as a supreme value in the constitutional order. Furthermore, constitutional schemes often create a presumption in favor of preserving a degree of legislative control over jurisdiction. In the case of collective responsibility, courts would need to transform mootness from a constitutional doctrine into a prudential doctrine that would enable them to decide otherwise 'moot cases' whenever a decision would help give true and concrete meaning to important public values. That is, however, an idealistic future projection rather than the present day reality of litigation for societal and political crimes.

Furthermore, in a standard criminal law setting, arrangements in which the whole group is punished for the faults or wrongdoing of a few constitute vicarious liability, and a person punished on account of another's wrongdoing is said to have been punished vicariously. Vicarious liability squarely conflicts with individual moral responsibility. ${ }^{71}$ For litigation purposes, such an attribution of group or collective liability is an arrangement that is unsuitable for most forms of harm or wrongdoing. ${ }^{72}$ However, the issue is not so clear when we are dealing with actions of the state institutions for instance. In this changed setting, Feinberg's second collective responsibility arrangement comes into the picture, which is

that it pertains to the determination of the limits posed upon legal issues over which a given court can exercise its judicial authority. It includes the legal concept of standing, which is commonly used to determine if the party bringing a legal suit is a party appropriate for establishing whether an actual adversarial act or issue exists. Essentially, justiciability seeks to address whether a court possesses the ability to provide adequate resolution of a disputed matter. Where a court feels it cannot offer such a final determination, the matter is rendered 'not justiciable.'

${ }^{71}$ This is despite the fact that Christian teachings interpret Jesus' crucifixion as his vicarious punishment for the sins of all humankind.

${ }^{72}$ See Victor Tadros, The Ends of Harm: The Moral Foundations of Criminal Law (Oxford University Press, 2011). 
based on the examination of implications for a group of individuals sharing a common agenda or could have possibly engaged in a similar harmful act. In this changed context, the ascription of criminal or moral responsibility requires that an act causing harm has actually occurred. ${ }^{73}$

To conclude, as I have discussed thus far, legal-philosophical debates in the field of collective responsibility clearly prove that an exaggerated conception of fault and responsibility could easily lead to the ascription of blameworthiness to groups and communities without having a solid ground for justiciability. This is clearly observable in Feinberg's categorizations, which constitute one of the finest examples of the legal philosophical analysis of collective responsibility. If so, formal organizations, such as business corporations, nation-states, armies or public bureaucracies appear to be the only legal actors that we could accrue justiciable forms of collective responsibility. That locks us back into the problem of responsibility being allocated only to formal units and their representatives thereof, and leaves us astray about societal accountability for mass political crimes.

Whether a true and systemic rectification of injury and harm aiming for corrective justice is at all possible concerning mass political crimes thus remains as a very troubling question. By whom justice must be performed is where almost all the attention seems to have focused on so far. If the injuries in question are divided into components of harm and wrong, each component's rectification would have to be considered separately. Although pecuniary compensation for such harms is practically plausible, money cannot act as a mediator between severely damaged lives and abusers of political power. Not all harms could be compensated, nor can it

\footnotetext{
${ }^{73} \mathrm{An}$ interesting case on the issue of vicarious liability is that of Lister v Hesley Hall [2002] 1 AC 215. In this case, the House of Lords reformed the law on vicarious liability, in the context of a claim arising over the intentional infliction of harm, by introducing the 'close connection' test. The immediate catalyst was the desire to facilitate recovery of damages on the part of victims of child abuse. The precise form the revision assumed was derived from two Canadian Supreme Court cases: Bazley v Curry [1999] 174 DLR (4th) 45 and Jacobi v Griffiths [1999] 174 DLR (4th) 7. Compared with other common law practices, Canadian jurisprudence contains a detailed review of the policy factors underpinning the law of vicarious liability and expresses the view that the most significant of these is 'enterprise liability'. See Douglas Brodie, "Enterprise Liability: Justifying Vicarious Liability" (2007) 27 Oxford Journal of Legal Studies 493. On the larger issue of permissibility to harm others and related legal liabilities, see Charlie Webb, "What is Unjust Enrichment?" (2009) 29 Oxford Journal of Legal Studies 215; Victor Tadros, "Duty and Liability" (2012) 24 Utilitas 259, and, Joanna Mary Firth \& Jonathan Quong, "Necessity, Moral Liability and Defensive Harm" (2012) 31 Law and Philosophy 673. The last two articles build upon Jeff McMahan's work on justified killing at times of war, which sets out a number of conditions for a person to be liable to attack, provided the attack is used to avert an objectively unjust threat defined in the following terms: (1) The threat, if realized, will wrongfully harm another; (2) the person is responsible for creating the threat; (3) killing the person is necessary to avert the threat, and (4) killing the person is a proportionate response to the threat. See Jeff McMahan, The Ethics of Killing: Problems at the Margins of Life (Oxford University Press, 2002).
} 
be said when compensation is paid, the status quo ante should be restored. There is no normative or conceptual reason for compensation to remedy societal harms. On the issue of the wrong, on the other hand, standard methods of rectification may or may not work, depending on the specific context of the injustice in question. For instance, to correct the wrongdoing by rectifying the harm may not at all be possible in the event of mass civilian deaths and disappearances. Deploying punitive damages may not be of much benefit for thousands or millions of displaced populations, either. The third, most common option embraced by international criminal law, punishment, also remains by and large symbolic. There may well be a need for an admission of causal and moral responsibility, public and institutional repudiation of the criminal act, substantive reforms at the state level, and, in some cases, disgorgement and reparations to be performed as a sign of a good faith effort to share the burden of the victims' suffering by the society at large. Although these cannot be coerced onto members of the society, the state and its institutions are obligated to take an institutional lead in this regard.

In this vein, this article offered a refutation of the litigation-heavy focus of international criminal law as it has been applied to mass societal and political crimes. Instead, it embraced the view that if so used, criminal law essentially becomes a stunted system of corrective rather than restorative justice. The concept of corrective justice is neither capable of offering solutions to societywide problems nor is it poised to deliver restorative justice for historical wrong doings. Rather than being corrective, what is required in instances such as crimes against humanity is an essentially protective function. The aim is the protection of legal subjects and valuable social interests from such harms in future. Here, I also tried to address the question of whether a statute of limitations on a historical injustice is morally justified. In essence, rectificatory justice calls for the ascription of a right to ask for rectification once an injustice has been perpetrated, without reference to a set time frame. To claim a statute of limitations on historical injustices amounts to inserting a temporal limit on the legitimacy of rights to rectification--a set amount of time following injustice after which claims of rectification could no longer be considered valid. However, since ascribing a right to rectification for an injustice is a requirement of fundamental justice, and since the temporal limit called for by a statute of limitations on injustice is a constraint on that requirement, the idea of a statute of limitations on historical injustices is morally justified only if one has substantive reasons for accepting this constraint such as establishment and maintenance of societal peace.

As a footnote to this entire debate, in legal philosophy, there is a peculiar argument that has been widely applied to substantiate the validity of claims for 
historic justice. It is known as the "non-identity argument". ${ }^{44}$ Accordingly, the harm to descendants of historically wronged peoples could be explained away not as deriving from the historic wrongs but from the failure to provide rectification to the previous generation for the harm they suffered. In this chain of injustices, each failure to provide rectification becomes the source of wrongful harm to the next. Non-identity philosophers argue that such chains form a bridge between the historic wrong and the harm suffered by living individuals today. In other words, past wrongs, for which original wrongdoers are responsible, harm descendants of original victims. Still, how do we distinguish claims of descendants of historic victims and claims made by others with unrelated interests in the rectification of the previous generation? A supplementary solution may be offered in the form of focusing on group harm and group membership. This approach ties individual harm to group harm rather than limiting justice claims to individual restitution or compensation. For instance, did slavery not harm the descendants of slaves? This is the classical example proving the shortcomings of the individual responsibility argument applied to reject the validity of claims for historic justice based on harms to descendants of victims of historic wrongs. According to the individual responsibility argument, if descendants are never harmed directly and personally by historic wrongs, they have no right to ask for rectification. This conclusion may be legally sound but it is morally unintuitive and must be debunked.

To end, due to the extensive the nature of harm involved in historic injustices, one must try in earnest to overcome the hurdle posed by the individual responsibility argument waged against historic justice claims. Historic injustices and the harms they generate are best understood as group or collective harms. The response to group harms has to have a collective component as well, because the remedies offered are again only meaningful in a social and political context. Claims for justice under such circumstances have to be grounded in harms currently suffered by living individuals as a function of the harms their group or community were subject to as part of historic wrongs. One common form of such harm, constitutive harm, significantly differs from the aggregative accounts of harm generally used by standard individual criminal litigation processes. Constitutive harm could not be addressed in that limited context at all. It is the type of harm people suffer as members of historically

\footnotetext{
${ }^{74}$ The non-identity problem emerged as a lively ethical debate concerning our obligations to future generations during the 1970s. It figured strongly in the works of Derek Parfit, Thomas Schwartz and Robert M. Adams. See Derek Parfit, Reasons and persons. (Oxford University Press, 1984); James Woodward, "The non-identity problem" (1986) 96 Ethics 804; Doran Smolkin, "The NonIdentity Problem and the Appeal to Future People's Rights" (1994) 32 The Southern journal of philosophy 315; Derek Parfit \& Samuel Scheffler. On what matters: volume one. Vol. 1. (Oxford University Press, 2011).
} 
wronged groups and communities. Therefore, historic injustice cases require a different account of responsibility, one that cannot be harnessed solely based on individual responsibility argumentation within the context of criminal justice jurisprudence. With all the reservations carefully examined in this article, we must make room for considerations pertaining to collective responsibility as a moral obligation, providing a context within which legal judgment should be firmly situated, though itself not catapulted to being a criminal charge. 